\title{
The importance of geologists and geology in tsunami science and tsunami hazard
}

\author{
DAVID R. TAPPIN \\ British Geological Survey, Keyworth, Nottingham, NG12 5GG, UK, \\ drta@bgs.ac.uk
}

\begin{abstract}
Up until the late 1980s geology contributed very little to the study of tsunamis because most were generated by earthquakes which were mainly the domain of seismologists. In 1987-88 however, sediments deposited as tsunamis flooded land were discovered. Subsequently they began to be widely used to identify prehistorical tsunami events, providing a longer-term record than previously available from historical accounts. The sediments offered an opportunity to better define tsunami frequency that could underpin improved risk assessment. When over 2200 people died from a catastrophic tsunami in Papua New Guinea (PNG) in 1998, and a submarine landslide was controversially proven to be the mechanism, marine geologists provided the leadership that led to the identification of this previously unrecognized danger. The catastrophic tsunami in the Indian Ocean in 2004 confirmed the critical importance of sedimentological research in understanding tsunamis. In 2011, the Japan earthquake and tsunami further confirmed the importance of both sediments in tsunami hazard mitigation and the dangers from seabed sediment failures in tsunami generation. Here we recount the history of geological involvement in tsunami science and its importance in advancing understanding of the extent, magnitude and nature of the hazard from tsunamis.
\end{abstract}

Until the late 1980s tsunami science was mostly the province of seismologists, numerical modellers, geophysicists and historians; tsunamis received little attention from geologists (e.g. Bailey \& Weir 1933; Coleman 1968, 1978). Earthquakes were considered the main, if not the only, mechanism that could generate elevated tsunami waves that were very destructive at the coast. Other tsunamigeneration mechanisms, such as submarine landslides, were not considered a major hazard despite evidence to the contrary such as from the Grand Banks event of 1929 (Bardet et al. 2003). Numerical tsunami modelling of submarine landslides was in large part theoretical (Jiang \& LeBlond 1992, 1994). The slow landslide failure velocities were perceived as inhibiting tsunami generation, in contrast to earthquake-generated tsunamis where rupture velocities of kilometres per second were regarded as instantaneous in the context of the relatively slow (metres per second) velocity of tsunami wave generation (Geist 2000; Ward 2001). Historians provided evidence on older tsunamis, hopefully for use in estimating tsunami frequency-magnitude relationships for future tsunami risk, although the limitations of historical data were recognized (Ambraseys \& Jackson 1990). When a paper (rarely) considered the geology of tsunamis, it was on the sediments deposited from inundation and authored by seismologists (e.g. Wright \& Mella 1963).
The involvement of geologists in tsunami research began in the early 1980s, with the first papers on deep-sea deposits in the Aegean Sea. Here, unusual seabed sediments, termed homogenites, were proposed as deposited from a tsunami generated by the Late Bronze Age eruption of Santorini (Kastens \& Cita 1981; Cita et al. 1984). In the Hawaiian Islands, boulders and coarse-grained gravels preserved at high elevations (hundreds of metres) were considered to result from tsunamis generated by large-scale volcanic collapse (Moore $\&$ Moore 1984). The early results from the Mediterranean and Pacific were controversial due to the uncertainty over whether there were tsunamis generated at these locations. In addition, this approach of using sediments to identify tsunamis from their sedimentary record had not been attempted before. The tsunami from the Late Bronze Age (LBA) eruption of Santorini had been a major controversy for decades (Marinatos 1939). Sand had been found in Minoan buildings on the coast and used as evidence for tsunami inundation; its origin was however disputed as it was located at sea level and the sand could have been deposited from storms or was present for religious purposes. Subsequent validation has been impossible because the sand deposits were destroyed during subsequent excavations. The Aegean Sea homogenites provided the first geological evidence in support of the tsunami hypothesis but, even today, the origin of the

From: Scourse, E. M., Chapman, N. A., Tappin, D. R. \& Wallis, S. R. (eds) Tsunamis: Geology,

Hazards and Risks. Geological Society, London, Special Publications, 456,

https://doi.org/10.1144/SP456.11

(1) British-Geological Survey@ NERG. Published by The Geological Society of London. All rights reserved.

For permissions: http://www.geolsoc.org.uk/permissions. Publishing disclaimer: www.geolsoc.org.uk/pub_ethics 


\section{R. TAPPIN}

homogenites remains controversial (see Pareschi et al. 2006; Shanmugam 2006; Weiss 2008; Polonia et al. 2013). The suggestion that the Hawaiian deposits were from tsunamis was groundbreaking because of their use in identifying tsunamis from volcanic collapse. Previously, the deposits were interpreted as laid down during sea-level highstands (Stearns 1978). Their origin is also still disputed (Stearns 1978; Rubin et al. 2000; McMurtry et al. 2004a).

In 1987 and 1988, two groundbreaking papers published on tsunami sediments demonstrated their potential in evaluating tsunami hazard. The first (Atwater 1987) was on prehistoric sediments in Cascadia, which identified a sequence of earthquakes and their associated tsunamis that extended back in time to over $10 \mathrm{ka}$ before present (BP). The second paper (Dawson et al. 1988) on sedimentary deposits in Scotland identified a major prehistoric tsunami from a massive submarine landslide (Storegga) located off Norway (Bugge 1983; Bugge et al. 1988). These sediments motivated the first attempt at numerical modelling of a tsunami from a submarine landslide mechanism (Harbitz 1992). In 1998, a devastating tsunami struck the north coast of Papua New Guinea (PNG) killing over 2200 people (Kawata et al. 1999). The associated $M_{\mathrm{w}} 7$ magnitude earthquake was too small to generate all of the elevated local run-ups of $15 \mathrm{~m}$. Amid confusion and controversy (e.g. Geist 2000), marine surveys organized in response to the disaster acquired hydroacoustic and sample data offshore of the impacted area. These surveys identified an offshore slump, which preliminary numerical simulations demonstrated to be the local tsunami mechanism (Tappin et al. 1999). The PNG event was seminal in identifying the major hazard from submarine landslides in tsunami generation. It was the first tsunami to be studied from responsive marine surveys led by geologists. Submarine landslides were well researched previously, but rarely in the context of tsunami generation and not by collaboration between geologists and numerical modellers (e.g. Grand Banks in 1929).

The 1987-88 research on tsunami sediments in the USA and Europe, together with the landslidegenerated PNG tsunami, resulted in the major involvement of geologists in tsunami science and the recognition of the contribution which geology could make to an improved understanding of tsunamis and their hazard. Demonstrating the mechanism of the PNG tsunami was seminal in confirming the tsunami hazard from submarine landslides. It was based on marine surveys carried out by geologists, with the geological interpretations underpinning the numerical tsunami models. Much later, the PNG tsunami was the first attempt to use inverse and forward modelling of tsunami sediments to determine tsunami characteristics (Jaffe et al. EDQ1 2007). More recent, devastating, events in the Indian Ocean (2004) and Japan (2011) have expanded this geological involvement in tsunami sediment characterization (e.g. Paris et al. 2007), in inverse modelling of tsunami-generation mechanisms (Spiske et al. 2010; Sugawara et al. 2014) and in research on submarine landslides in tsunami generation (Tappin et al. 2007, 2014). Storegga, PNG and most recently Japan have led to an increased realization of the tsunami hazard from submarine landslides.

Here it is recounted how over the past $c .30$ years geologists became increasingly involved in tsunami science and how they have contributed to an improved understanding of tsunami mechanisms and their hazard. Although there were earlier, isolated precursors to the main 'catalyst' events identified above, it was during the 1980s that 'geology' became significant in advancing tsunami science; this advancement was initially from the application of tsunami sediments, followed by an improved understanding of tsunami frequency, hazard and risk, and more recently, with the Japan tsunami, from the use of sediments as a basis for inverse numerical models of tsunami-generation mechanisms (e.g. Sugawara et al. 2014). The motivations for this paper were the two meetings held in Japan and the United Kingdom in 2014 and 2015 on the theme of 'Tsunami Hazards and Risks: Using the Geological Record'. The focus of the Japan meeting was the use of tsunami sediments in the mitigation of tsunami hazard. The aim of the UK meeting was to bring together geologists and hazard and risk modellers. In this paper the use of the geological record in contributing to tsunami hazard is extended by the addition of how the identification of submarine landslides have led to their recognition as a major hazard in tsunami generation, a hazard previously overlooked (Bardet et al. 2003; Løvholt et al. 2015). To underpin realistic modelling of tsunamis generated from submarine landslides requires their architectures to be determined from hydroacoustic data, including multibeam echosounders (MBES) and seismics. Mapping of seabed failures has led to the transition from theoretical numerical models, which suggested that landslides were ineffective in tsunami generation (LeBlond \& Jones 1995), to realistic, event-based models that prove otherwise (Harbitz 1992; Tappin et al. 1999). The use of the term 'geology' is interpretative in the sense that subseabed structure can be determined from remote data such as multibeam echosoundings and seismics. It is also recognized that the characterization of tsunami sediments and their discrimination from other depositional mechanisms is still undergoing review (see Shanmugam 2012), so here the focus 


\section{IMPORTANCE OF GEOLOGY IN TSUMANI SCIENCE}

is on well-studied examples from well-established mechanisms.

\section{Tsunami sediments}

Sediments deposited from tsunamis are mainly recognized on land. Those described from the seabed are rare and their identification and application in tsunami hazard assessment are more controversial (see Shanmugam 2006; Dawson \& Stewart 2007), but they are covered here briefly for completeness (Fig. 1). Seabed tsunami sediments are found in deeper, oceanic water depths, include the homogenites in the eastern Mediterranean noted above. There are also shallow-water shelf deposits resulting from tsunami backwash (or backflow). Turbidites in the deep ocean have been well studied (e.g. Heezen \& Ewing 1954; Kuenen 1957; Piper et al. 1988). Triggered by earthquakes, and in combination with onshore sediments, turbidites can be proxies for large-scale prehistoric earthquake events. Cascadia, on the west coast of the USA, is the best-studied area (Goldfinger et al. 2012). Here, turbidites along the oceanic margin were first researched in the 1970s (Griggs \& Kulm 1970), with the first attempt to use these to earthquake cycles in 1990 (Adams 1990) and si quent research developed by Goldfinger et al. (2012). As the distal parts of submarine landslides, turbidites can be used in dating these (e.g. Normark et al. 2004). High-resolution age dating of submarine landslides is important in establishing relationships to climate change, which is a major control on sediment failure (Maslin et al. 2004) although still poorly understood (Urlaub et al. 2013). Backwash flow follows the maximum inundation of tsunami waves, after which the water recedes seawards. Backwash deposits on land are well described
(Dawson 1994; Paris et al. 2007); however, in the ocean they are poorly researched. Interpretations are speculative because there are no reliable measurements of this process and few recent examples (Fig. 1; Dawson \& Stewart 2007; Ikehara et al. 2014). The best evidence for backwash flow is from video footage of sediment plumes moving offshore from the Indian Ocean and Japan events (see Tappin et al. 2012). The backwash sediment flushed seawards has rarely been studied, but from the few case histories published on shelf deposits its longterm preservation potential is probably low because of reworking by longshore currents (Tappin et al. 2012) and storms (Noda et al. 2007; Sakuna et al. 2012; Feldens et al. 2012). Reworking compromises discrimination between tsunamis and storm deposits. On the outer shelf of Japan, the preservation of backwash deposits from the 2011 tsunami is considered likely only over short timescales (Ikehara et al. 2014). Nearer shore, the sediment flushed seawards was soon eroded by longshore drift and redeposited on the adjacent coast, where it repaired major coastal breaches (Tappin et al. 2012). The use of shallow-water tsunami deposits on the continental shelf in hazard assessment at present is therefore considered too poorly understood to be considered further.

Our imperative here is therefore on coastal deposits, particularly those from recent, historical and Quaternary events. Onshore sedimentary deposits from the older (pre-Quaternary) geological record have been attributed to tsunamis (e.g. Le Roux \& Vargas 2005). Where the tsunami mechanism can be established, for example Chicxulub (e.g. Goto et al. 2008b), deposit origins can be validated; where the mechanism is more uncertain, as for many of the deposits $n$ he west coast of South America, there may her be considerable uncertainty (e.g. Bailey \& Weir 1933; Spiske et al.

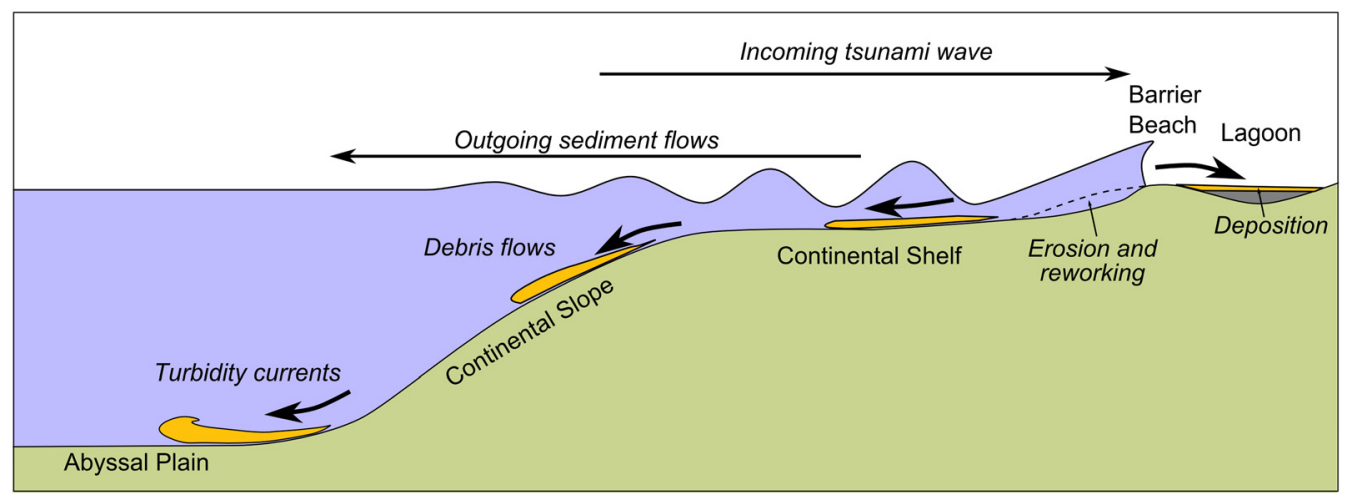

Fig. 1. Schematic illustration of principal pathways of tsunami sediment transport and deposition (Reproduced from MikeNorton; Wikipedia). 


\section{R. TAPPIN}

2014). The focus here is therefore on those mainly recent, on-land deposits which can improve hazard assessment through: (1) better understanding of tsunami frequency and impact; (2) the validation of numerical models; and (3) as a basis for inverse modelling of tsunami inundation an tomamigeneration mechanisms, although the upprication of these methodologies is still in its infancy (Huntington et al. 2007). These deposits include both fine-grained sediments and coarse-grained gravel/ boulder deposits.

\section{Early history of research (pre-1980)}

Written observations of tsunami sediment deposition date back to 1868 from the Arica earthquake off Chile, where the US Postal Steamer Wateree (Fig. 2) was carried inland $430 \mathrm{~m}$ by a wave $18 \mathrm{~m}$ high at the coast and buried under a mass of sand and water (recorded in Myles 1985). The first scientific publication to suggest that tsunamis might be responsible for sediment deposition is Bailey \& Weir (1933) on sediments of Jurassic age located on the west coast of Scotland. No further studies of tsunami inundation and sedimentation from historical or recent large earthquakes were published until the 1946 Aleutian tsunami, which struck
Hawaii (Shepard et al. 1950). The first observational evidence for tsunamis transporting sediment was a series of photographs also from Hawaii from the 1957 earthquake in the Aleutians (referred to in Bourgeois 2009). Observations were reported of sediment deposition from the Chile tsunami of 1960 (Wright \& Mella 1963) and the Alaska earthquake of 1964 (Reimnitz \& Marshall 1965), but no detailed interpretations made. The 1960 Chile event left a 1-2 cm veneer of sand over the coastal lowlands (Wright \& Mella 1963). There are numerous descriptions from Japan (e.g. Kon'no 1961), but these publications are mostly in Japanese so less accessible (Bourgeois 2009). Descriptions of the Suva earthquake and tsunami of 1953 were perhaps some of the first of the modern era to suggest an associated submarine landslide-generated tsunami, which deposited coral boulders on the adjacent reef (Houtz 1962). Probably the first modern 'geologically' focused paper that described tsunami sedimentation was by Coleman (1968).

\section{Seminal events of the 1980-90s}

The first geological evidence for sediments deposited from prehistoric tsunamis, which identified their potential for use in mitigation, was from

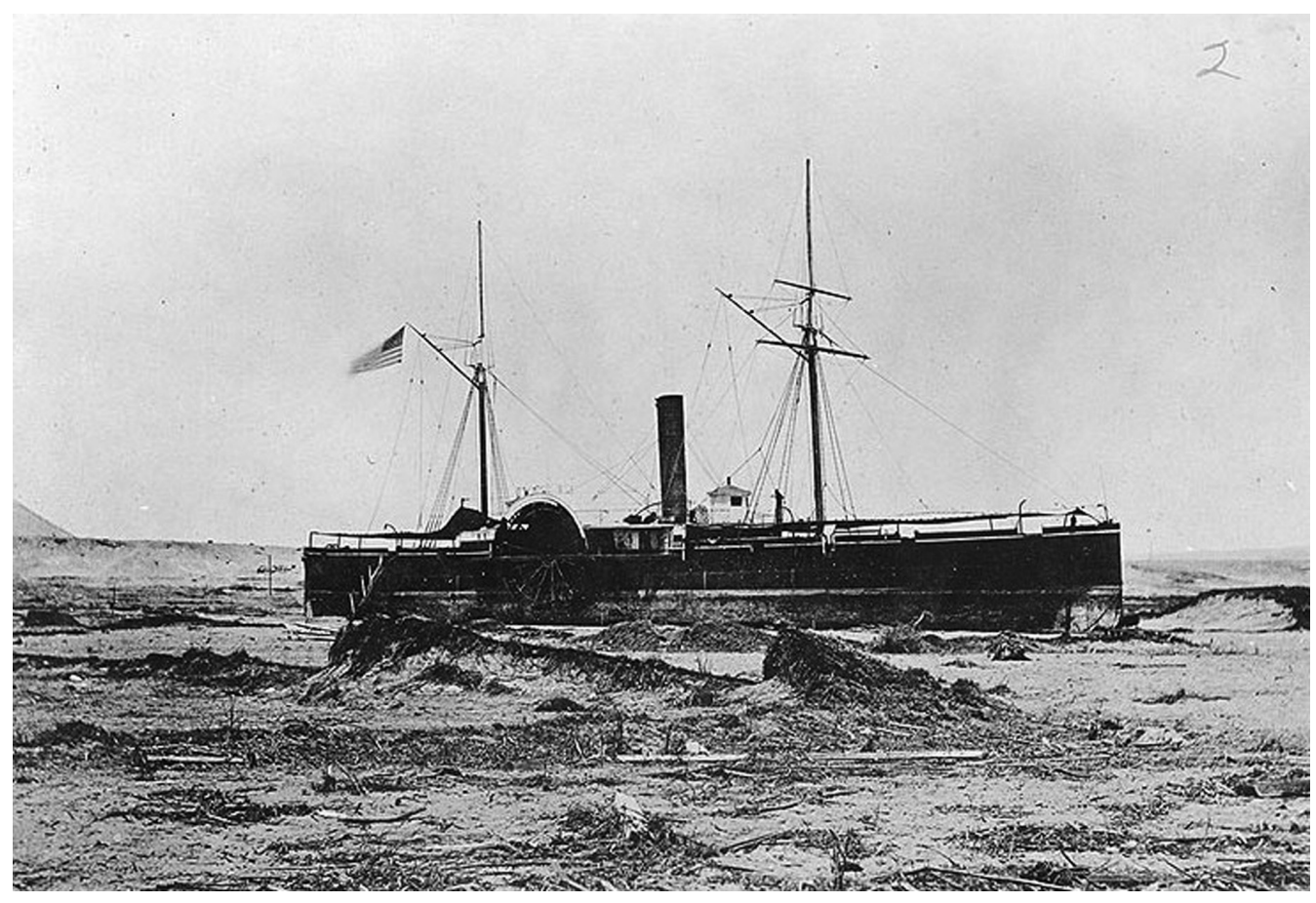

Fig. 2. USS Wateree (1863) beached at Arica, Chile, 430 yards above the usual high water mark, after she was deposited there by a tidal wave on 13 August 1868. Note the tsunami sand in the foreground (U.S. Navy photograph). 


\section{IMPORTANCE OF GEOLOGY IN TSUMANI SCIENCE}

North America (Atwater 1987). The sediments were up to $10 \mathrm{ka}$ old and preserved in sand sheets interbedded with marsh muds from the outer coast of Washington State. They were interpreted as deposited from earthquake-generated tsunamis. Recognition of the tsunami origin of the sediments led to the identification of earthquakes and tsunamis of much earlier age than that provided by historical records (up to 200 years old). A year later Dawson et al. (1988) described an unusual sand deposit (Fig. 3) within uplifted coastal sediment sequences in Scotland, which they attributed to a tsunami generated from the Storegga submarine landslide off the Norwegian coast (Jansen et al. 1987; Bondevik et al. 2005a). Deposits from Storegga had been described from the Shetland Islands by Birnie (1981), but had not been identified as originating from a tsunami. Along the Washington coast, the only explanation for the sediments was by rapid coastal subsidence from local earthquakes that generated tsunamis. In Scotland, radiocarbon dating of the sediments and Storegga landslide proved a close coeval correspondence. The identification of the deposits in Scotland motivated Harbitz (1992) to simulate a tsunami from a submarine landslide event, the first time that numerical modelling of a recorded submarine landside tsunami had been attempted.

The evidence for the origin of the sands in Cascadia and Scotland was circumstantial because their deposition from tsunamis had not been observed. For the first time the research was also by sedimentologists, unlike observations made at earlier historical events noted above which were by non-experts. Confirmatory evidence for the Cascadia research on the tsunami origin of the ans came first from a historical event in Japan. I east coast of Honshu Island, sands preserved in lake sediments were also identified as laid down by a tsunami, generated from the 1983 Sea of Japan Earthquake (Minoura \& Nakaya 1991). Older, underlying sands were dated as far back as 2700 years BP, confirming the association between tsunami inundation and earthquake subsidence as observed previously in Cascadia. Further confirmation of the Cascadia and Scottish interpretations of tsunami sand deposition was lacking because of an absence of post-1987 tsunami events. A devastating tsunami struck Flores Island in December 1992 killing 2190 people, over half of

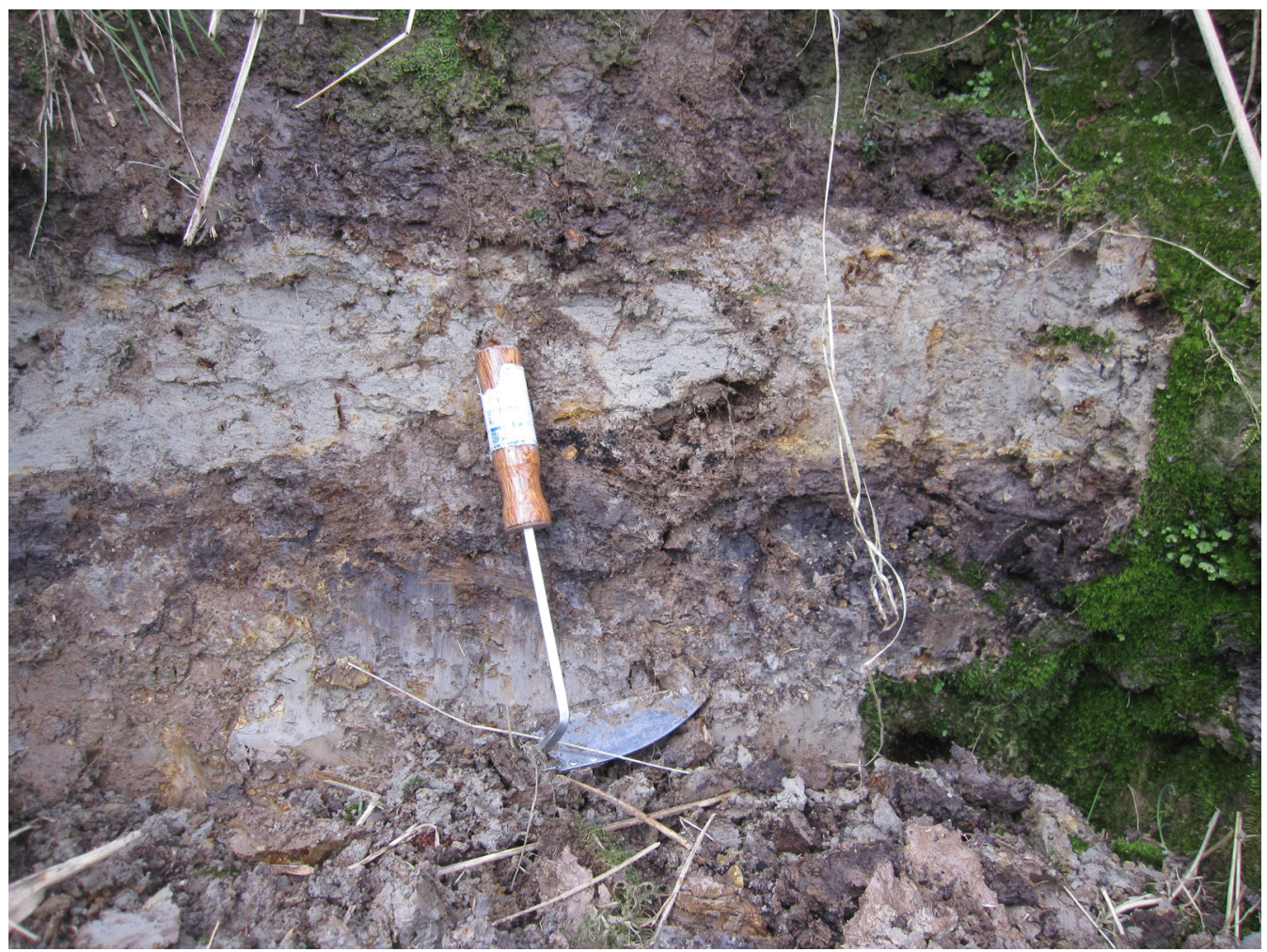

Fig. 3. Tsunami sediments (pale grey by the handle of the Nejiri-gama) from the east coast of Scotland generated by the Storegga tsunami of $8.2 \mathrm{ka}$ BP. Nejiri-gama $23 \mathrm{~cm}$ long (Photograph, D.R. Tappin). 


\section{R. TAPPIN}

whom died in the tsunami. The Flores tsunami was one of the first investigated by specifically organized, responsive, field surveys (Yeh et al. 1993). It was the first of the modern age to include geologists in the field team (Shi et al. 1995). The 1991 Japanese research by Minoura and Nakaya was based solely on core samples, but at Flores field surveys reported on both the geomorphology of tsunami impact and the sediments deposited (Shi et al. 1995; Minoura et al. 1997). For the first time, there was a direct correlation between an observed tsunami and the sediments deposited. Although the Flores surveys were aimed at understanding the sedimentary processes associated with tsunami inundation, they were also planned as the first attempt to use a recent event to improve the identification and interpretation of older, palaeotsunami deposits (Shi et al. 1995).

\section{Scientific objectives}

Two primary objectives of sedimentological research emerged from the early tsunami studies. The first was to establish unequivocal sedimentary characteristics of tsunami deposits that would allow their discrimination from other, high-energy depositional mechanisms such as storms (e.g. Shi et al. 1995; Dominey-Howes et al. 2006). The second was to use these sedimentary characteristics to identify older, prehistoric sediments. Identification of ancient, prehistoric tsunami sediments as a record of older events, together with their reliable age dating, would allow the quantification of tsunami recurrence intervals, improving tsunami hazard and risk assessment. Initially, discrimination of finegrained tsunami sediments was based on simple criteria such as the extent of deposits, landwards grain-size fining and deposit thinning (fine-grained tsunami sediments were normally graded and storm deposits laminated), and rip-up clasts were significant (Morton et al. 2007). Discrimination of coarser-grained, boulder deposits was from imbrication and boulder orientation. There were also the first attempts at mathematical modelling of boulder transport (Moore \& Moore 1988; Nott 1997, 2003 ; Weiss 2012).

Based on the analysis of sediments from more recent events, such as PNG and the Indian Ocean, objectives that are more ambitious were identified. Detailed grain size analysis of tsunami deposits from PNG for the first time were used to model onshore flow depth and speed, from which tsunami size could be quantified (Gelfenbaum \& Jaffe 2003). The results were to provide the key for longterm hazard assessments based on tsunami source mechanisms (e.g. earthquake fault slip or submarine landslides) inverted from calculated tsunami wave characteristics. After the Indian Ocean tsunami of
2004, based on the new and developing quantitative approaches developed first for PNG Huntington et al. (2007) identified two further key challenges: (1) closing the knowledge gap in linking modern events to their deposits with an improved understanding of tsunami sediment transport; and (2) adapting this relationship to better interpret the geologic record.

\section{Early advances (1990s-2004)}

From the early 1990s there was a steady increase in research on tsunami deposits as reflected in the number of peer-reviewed papers published (see Bourgeois 2009, fig. 3.2). The research was from responsive field surveys, which became the norm after the Nicaragua tsunami of 1992 (Satake et al. 1993), but also because of continued work on seminal events such as Storegga and in the Hawaiian Islands. The focus was mainly on the convergent margins of the NW Pacific and Japan, and the north Atlantic passive margin. Research in other areas where the hazard is significant, such as New Zealand, was constrained because of the challenges in proving the tsunami sediment provenance (Goff et al. 2001). The experience gained from the early studies on Cascadia and Storegga and more recent events (e.g. Flores in 1992) was used to research older historical events including Lisbon in 1755 (Dawson et al. 1995), Grand Banks in 1929 (Tuttle et al. 2004; Moore et al. 2007) and events in New Zealand (Goff et al. 2001). In Cascadia, further research identified six major earthquakes over the past $7 \mathrm{ka}$, three of which at least were associated with tsunamis. During the past $3.5 \mathrm{ka}$, there were seven extensive tsunamis (Atwater \& HemphillHaley 1997; Peters et al. 2007). At some locations, the record extended back to $14 \mathrm{ka} \mathrm{BP}$, with three events older than $3.5 \mathrm{ka}$ (Peters et al. 2007). Research on the Storegga tsunami confirmed previously established relationships between the landslide and the sediments in Scotland. This was based on additional evidence from sediments preserved in elevated lakes in Norway (Bondevik et al. 1997a, 2005a) and in the Faeroe Islands (Grauert et al. 2001). At the end of the period 1990-2004, the study of tsunami sediments had expanded from a few publications based on circumstantial relationships between cause and effect (as with Cascadia and Storegga) to the reporting of recent events validated by observations of tsunami inundation. The tsunami record at some locations now extended back beyond historical reporting. Preliminary identification of simple sediment characteristics led to optimism that, with time, absolute criteria would be identified for discrimination of tsunami deposits from other high-energy mechanisms of deposition. 


\section{IMPORTANCE OF GEOLOGY IN TSUMANI SCIENCE}

Considering the limited published research, there were a large number of review papers (Bourgeois 2009). New terms, such as tsunamites, were introduced to describe the sediments, although these were later subject to some controversy over their definition (Shanmugam 2006). There were several special journal issues produced (Einsele 1996; Shiki et al. 2000), and an edited book was in preparation (later published as Shiki et al. 2008). Then the most catastrophic tsunami ever generated struck in the Indian Ocean.

\section{Catastrophic events, advances and controversy: post-2004}

The Indian Ocean tsunami led to major advances in tsunami sediment science because it generated a major surge in research. Observations of the tsunami flooding the land confirmed the sedimentary evidence for the tsunami source of the coastal sediments deposited. The Indian Ocean tsunami was the largest recorded event where there was a positive association between inundation and deposition. The responsive tsunami surveys carried out since 1992 (on Nicaragua) provided the basis for the management of the Indian Ocean field surveys which, carried out over the whole region impacted, provided a comprehensive database of the tsunami impact. An even greater surprise than the Indian Ocean tsunami was the Japanese event of 2011. Japan had the most sophisticated mitigation and response strategies of any country in the world in contrast to the Indian Ocean where there was no warning system, yet 19000 people died. The research on the Indian Ocean tsunami resulted in improved understanding of qualitative depositional mechanisms, whereas the advances from Japan were quantitative. Although the advances from these events (and other smaller events) were significant; the original objectives identified above - tsunami deposit discrimination and its use in identifying older deposits - were not quite as successful as envisaged. Sedimentary characteristics have been identified, but absolute characterization of tsunami deposits has not been achieved (Shanmugam 2012). Coarser-grained (boulder) deposits have been especially difficult to characterize (Morton et al. 2006).

Sedimentary characteristics of fine-grained, tsunami sediments are now being used more effectively to estimate flow velocities from which wave magnitudes are derived. Preliminary studies (e.g. Jaffe et al. 2011; Sugawara et al. 2012; Tang \& Weiss 2015) show that inverse modelling of these characteristics can be used to identify tsunami-generation mechanisms (MacInnes et al. 2010; Sugawara et al. 2012). However, palaeotsunami magnitudes and inflow characteristics derived from inverse numerical models, such as TsuSedMod (Jaffe \&
Gelfenbuam 2007; Spiske et al. 2010), are dependent on the successful discrimination of inflow from backflow deposits (Bahlburg \& Spiske 2012). Most studies are of tsunami deposits from earthquakes; there are still only a few descriptions of deposits from submarine landslides (Dawson et al. 1988; Bondevik et al. 2003; Gelfenbaum \& Jaffe 2003). Submarine landslide deposit research is still focused on Storegga and their sediments deposited on the coastlines of the north Atlantic (e.g. Bondevik et al. 2005a).

Intensive studies of the catastrophic Indian Ocean, 2004 and Japan, 2011 events show that previously proposed 'simple' discriminants described above are not necessarily unique to tsunami sediments; they may also be found in storm deposits. The assumption that tsunami sediments are only deposited from suspension settling (giving finingupward beds) has given way to the recognition that they also result from bedload (traction) transport (giving laminated sediments), which compromises previous discrimination (Paris et al. 2007). Commonly deposited sediments during both the Indian Ocean and Japan events were laminated (from traction currents; Paris et al. 2007; Szczuciński et al. 2012). In addition, marine microfossils (diatoms and foraminifera), previously considered characteristic of tsunami sediments as in the Indian Ocean (Sawai et al. 2009), were rarely found in sediments from the Japan 2011 tsunami (Szczuciński et al. 2012). Without observational evidence of tsunami inundation, the identification in isolation of 'absolute' sedimentological criteria that allow identification of a palaeotsunami sediment does not yet seem possible.

Despite the recognition that simple discriminatory criteria are not as 'absolute' as previously proposed (e.g. Morton et al. 2007), there have been major advances in characterizing fine-grained sediments and the controls on deposition. Tsunami deposits vary because controls on sedimentation are richly variable. These controls include: (1) coastal and nearshore morphology; (2) the elevation of tsunami waves at the coast; (3) run-up (maximum inland elevation reached by the inundation); (4) the nature and amount of the sediment available for erosion; and (5) the preservation potential of the sedimentary imprint laid down during inundation. As a result, tsunami deposits are complex. There is positive news, however. Whereas there may not be absolute distinguishing sedimentological criteria that can be extrapolated between different locations, at any single location it is possible to discriminate between tsunami and storm deposits where both are present (e.g. Nanayama et al. 2000; Goff et al. 2004; Tuttle et al. 2004; Switzer et al. 2005). Research on the sediment history of tsunamis at individual locations can be used in improved 


\section{R. TAPPIN}

understanding of event recurrence and frequency, as in Cascadia and Japan (Atwater \& Hemphill-Haley 1997; Minoura et al. 2001; Ishimura \& Miyauchi 2015). The surveys focused on the catastrophic events in the Indian Ocean and Japan yielded major advances in understanding of the (mainly) fine-grained sediments deposited, but also boulders. With the Indian Ocean tsunami, understanding was improved on characterizing the sediments and investigating their preservation and alteration over time. With Japan, the advances were in the geochemical characterization of the sediments and their use in numerical models (see 'Tsunami sediments in numerical modelling' below). In both instances, the focus was also on characterizing the deposits to provide valid diagnostic criteria to help identify palaeotsunami deposits at specific locations, from which the tsunami hazard at the location is better understood (Jankaew et al. 2008; Sugawara et al. 2012).

\section{Analysis: new technological developments}

Sedimentological analysis of deposits has advanced considerably, but new analytical techniques provide additional methodologies to support classical approaches. The use of geochemical profiling ('toolkits') of recent deposits has advanced considerably (Chagué-Goff et al. 2011, 2012). For example, geochemical analysis of soil profiles landwards of the limit of sand deposition now allow the maximum extent of tsunami inundation to be identified (e.g. Goto et al. 2011; Chagué-Goff et al. 2012). There are constraints with older deposits, however, where the use of geochemistry may be limited because of poor sediment preservation and postdepositional alteration (taphonomy) and reworking by rainfall, wind action, bioturbation and human activity (Szczuciński 2011, 2013). Other developing branches of study on tsunami sediments include the use of heavy minerals in their characterization, anisotropy of magnetic susceptibility (AMS) and $\mathrm{X}$-ray tomography. Analysis of heavy minerals is now being used to discriminate tsunami deposits from other high-energy depositional mechanisms such as storms (e.g. Costa et al. 2017). AMS provides the sedimentary fabric of the tsunami deposits from which flow directions are identified. There are still too few events studied, but this technique has been used successfully on sandy deposits in northern Sumatra from the Indian Ocean tsunami (Wassmer et al. 2010) and pyroclastic volcanic deposits from the Krakatau eruption of 1883 (Paris et al. 2014). X-ray tomography is the most recent development, but has only been used on sandy deposits from the Lisbon tsunami of 1775 (Falvard \& Paris 2017). It allows the characterization of grain-size distribution, structures, component analysis and sedimentary fabric of fine-grained unconsolidated tsunami deposits at resolutions down to particle scale. The results are validated by comparing to data obtained using other techniques such as laser diffraction, AMS and X-ray microfluorescence.

\section{Numerical modelling}

The study of deposits from the PNG, the Indian Ocean and Japan tsunamis has resulted in improved insights into the processes and forces acting during tsunami inundation based on the hydrodynamic characteristics of the tsunami that control sediment deposition (Jaffe \& Gelfenbaum 2002; Spiske et al. 2008; Witter et al. 2012). Numerical inverse modelling, however, is still at an early stage of development and a more general physical understanding of hydrodynamic processes and their interplay with sediment is required to advance this approach (Cheng \& Weiss 2013). For instance, studies of the deposits may be used to assess the tsunami flow velocity and the depth of tsunami inundations. As noted above, however, inflow and backflow deposits have to be reliably identified for the numerical models to be valid. Notwithstanding, tsunami sediments have been used to identify their earthquake source mechanisms. On the west coast of Kamchatka, alongshore distribution of tsunami sediments was used to discriminate between two earthquakes that took place in 1969 and 1971 (Martin et al. 2008). A study of the Kamchatka earthquake tsunami of 1952, based on the variable distribution of tsunami deposits, resulted in new models of earthquake slip (MacInnes et al. 2010).

The major scientific response to the Indian Ocean tsunami resulted in impacted coastlines being researched for tsunami sediments (e.g. Borrero 2005; Kench et al. 2006; Paris et al. 2007; Goto et al. 2008a; Morton et al. 2008). The devastating Japan tsunami of 2011 resulted in the acquisition of an extensive and comprehensive dataset of the sediments deposited. It provided another major opportunity to improve understanding of tsunami sedimentation and its use in mitigation (e.g. Goto et al. 2011; Szczuciński et al. 2012). The response to the coastal inundation was the most intensive of any previous event, with both national and international teams involved in field studies (e.g. Goto et al. 2011; Mori et al. 2011). From the Japanese field surveys, there were a number of new insights into tsunami sediment deposition: (1) tsunami inundation much greater than the depositional limit of sand; (2) geochemical analysis of muddy sediments that identify tsunami inundation beyond the limit of sand deposition; (3) a minor component of marine microfossils in tsunami sediment; (4) coarse gravel deposits thicker than sands; and (5) varied beach erosion, limited in some areas but intense in others 


\section{IMPORTANCE OF GEOLOGY IN TSUMANI SCIENCE}

(Goto et al. 2011). These new observations formed the basis for improved understanding of older deposits preserved in the region of the 2011 inundation. One of the most devastating older historic events was the Jogan tsunami of 869. Comparison between the sediments from the two events (Minoura et al. 2001) showed the inland inundation of Jogan to be far greater than previously recognized. In addition, from inverse modelling of the deposits the 869 earthquake magnitude was re-evaluated and found to be much greater than previously estimated (Sugawara et al. 2013). The result was a major advance in understanding earthquake frequencies. The Japan, 2011 event therefore offered an important opportunity to improve: (1) how inland inundation can be identified; (2) the methodology of using inversion of sedimentary data to establish the 2011 earthquake rupture magnitude and extent; and (3) existing models of older, comparable, events in the same region (Sawai et al. 2012; Sugawara et al. 2013). The scientific advances were both qualitative (e.g. Goto et al. 2011) and quantitative (Sugawara \& Goto 2012; Sugawara et al. 2014).

\section{Boulder/gravel deposits}

Tsunamis deposit individual boulder trains and boulder groups (Goto et al. 2007; Ramalho et al. 2015) as well as boulders entrained in finer-grained sediment (Paris et al. 2004; Yamada et al. 2014). The first attempts to understand the hydrodynamic mechanisms of deposition of both types of deposit were by Nott (1997); there are still uncertainties however because boulders are moved differently by storms and tsunamis, resulting in different deposit characteristics (Weiss 2012). Discrimination of tsunami boulder deposits from storm deposits is problematic (Felton 2002; Hall et al. 2006; Morton et al. 2006), but recent work suggests that tsunamis produce disorganized boulder deposits whereas, storms organize boulders along lines and clusters (Goto et al. 2010b; Weiss 2012). Individual boulders cast ashore have been used to identify tsunami impact (Goto et al. 2010b) as well as in validating tsunami-generation mechanisms and their magnitude (Moore et al. 1995; McMurtry et al. $2004 a$ ). As with fine-grained sediments, discrimination is possible where both storm and tsunami deposits are preserved at the same location (Goto et al. 2010b).

Boulder deposits of tsunami origin first described as far back as 1933 from eastern Scotland are coarse-grained conglomerates attributed to earthquake-triggered landslides, which were reworked by an ensuing tsunami (Bailey \& Weir 1933). Subsequent research by Pickering (1984) proposed only a fault-scarp origin for the deposits, but surprisingly did not cite the earlier 1933 paper. This is unfortunate, because the opportunity to reconsider the previous interpretation of a tsunami origin in the context of improved sedimentological understanding was missed. Interpretation of other boulder deposits has also been controversial, for example discrimination between recent storm and boulder deposits on the Aruba, Bonaire and Curaçao $(\mathrm{ABC})$ islands in the southern Caribbean (see Morton et al. 2006).

Some of the most controversial coarse-grained tsunami deposits are in the Hawaiian Islands. Here, boulders and marine gravels up to $200 \mathrm{~m}$ above present sea level (Fig. 4) are attributed to tsunamis from volcanic flank collapse (Moore 1964; Moore \& Moore 1984, 1988; Moore et al. 1989). The deposits were first interpreted as marine highstands (Stearns \& Macdonald 1946; Stearns 1978), then as tsunami deposits (in the Moore papers) and then again as highstands (Rubin et al. 2001). The best-preserved deposits are on Lanai Island, and recent interpretations attribute their origin to the last two interglacial highstands at 120 and $240 \mathrm{ka}$ BP (Grigg \& Jones 1997; Felton et al. 2000; Rubin et al. 2000). A problem in interpreting the origin of the deposits is the similarity between the ages of the highstands and the triggering of the landslides. The submarine landslides from volcanic collapse are probably triggered at the end of glaciations, at which time sea levels were rising rapidly (McMurtry et al. 1999; Quidelleur et al. 2008). The origin of the deposits are therefore quite complex. The importance in establishing the origin of the Hawaiian gravels is two-fold: (1) to prove (or not) the tsunami hazard from the volcanic collapses mapped offshore the islands (Fig. 5); and (2) to validate tsunami run-up elevations from the numerical models of volcanic collapse (McMurtry et al. 2004b, fig. 3 ). The controversy over the origin of the deposits (from highstands or tsunamis) compromises their use in identifying the tsunami-generating potential from volcanic collapse.

The basis of the controversy over the interpretation of the Hawaiian deposits is the uncertainty in the elevations of the islands when the sediments were deposited. The flank collapses (and sediments) are thousands to hundreds of thousands years old. The elevations of the Hawaiian Islands have changed since these deposits took place; some have been uplifted whereas others have subsided. Only the Big Island has a well-established vertical tectonic history, which shows subsidence for hundreds of thousands of years (Ludwig et al. 1991). The elevation of the sediments at their time of deposition is calculated from their age, present elevation and the known subsidence rate of the island. In the north of the Big Island at Kohala, coralliferous gravels are now at sea level. These deposits 


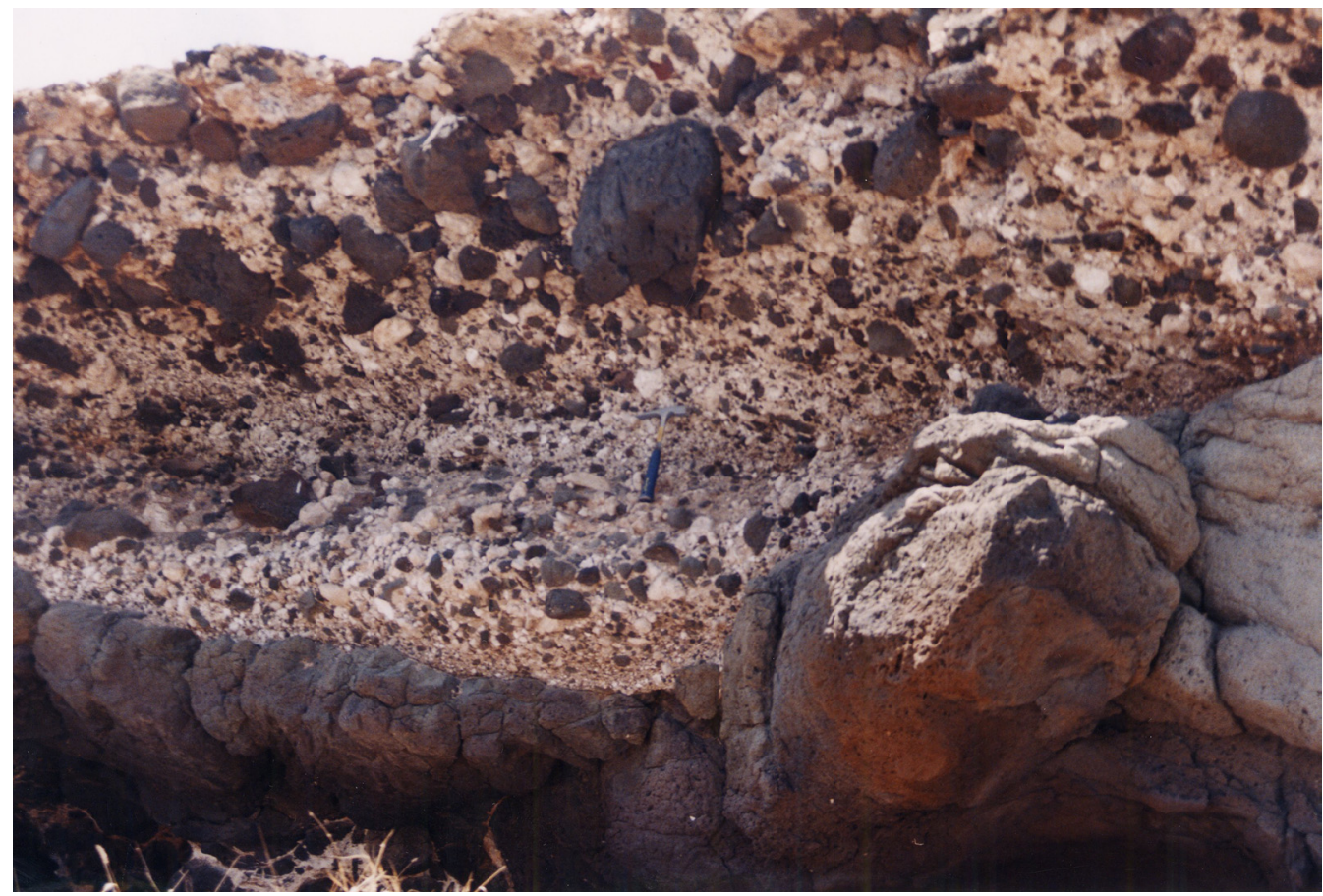

Fig. 4. Tsunami sediments from Lanai Island, Hawaii deposited from large-scale volcanic flank collapse. Note the two coarsening-upwards cycles. Geological hammer $40 \mathrm{~cm}$ (Photograph, D.R. Tappin).

are dated at $120 \mathrm{ka} \mathrm{BP}$, the same age as the Alika 2 landslide just offshore (Fig. 5). Alika 2 is the most likely source of the tsunami which laid the deposits down (McMurtry et al. 2004a). Since deposition $120 \mathrm{ka}$ ago, Hawaii has been subsiding at a rate of $3.4 \mathrm{~mm} \mathrm{a}^{-1}$. The elevation of the sediments at time of deposition was therefore $\sim 400 \mathrm{~m}$ above present sea level. Numerical tsunami modelling of the failure of the Alika phase-2 giant submarine landslide results in tsunami run-ups of hundreds of metres on Hawaii and Lanai (McMurtry et al. 2004b, fig. 3). The most recent evidence from the Big Island therefore confirms that the deposits are indeed from a tsunami hundreds of metres in elevation. The fringing coastal (? tsunami) deposits on both Hawaii and Lanai are compositionally very similar. It therefore seems likely that the explanation for the gravels at both locations (The Big Island and Lanai), at least for the youngest deposits dated at $120 \mathrm{ka} \mathrm{BP}$, is a tsunami generated during postglacial volcanic collapse.

Individual boulders without associated finergrained sediment are common along many shorelines, and have the potential to improve tsunami hazard assessment. As with fine-grained tsunami deposits, however, there is considerable controversy over their discrimination from the other potential depositional mechanisms such as storms, especially where both storms and tsunamis affect the same coast (Hearty 1997; Noormets et al. 2002; Mastronuzzi \& Sanso 2004; Mylroie 2008; Switzer \& Burston 2010; Weiss \& Diplas 2015). The elevation of the deposits is an important discriminant (Ramalho et al. 2015) but local tectonic history needs to be established to avoid conflict, such as in Hawaii (Rubin et al. 2000; McMurtry et al. 2004a). Apart from boulder elevations, there are geomorphological and sedimentological methodologies proposed that might discriminate between the different mechanisms (e.g. Morton et al. 2006; Spiske et al. 2008; Goto et al. 2010a). Unfortunately, there are still too few case studies based on a systematic sedimentological approach to deposit analysis to formulate robust criteria for distinguishing between coarseclast storm and tsunami deposits (Morton et al. 2006).

\section{Submarine landslide tsunami}

The potential for submarine landslides to generate tsunamis has been known for over 100 years (Milne 1898; Montessus de Ballore 1907; Gutenberg 1939), yet most research has been on 


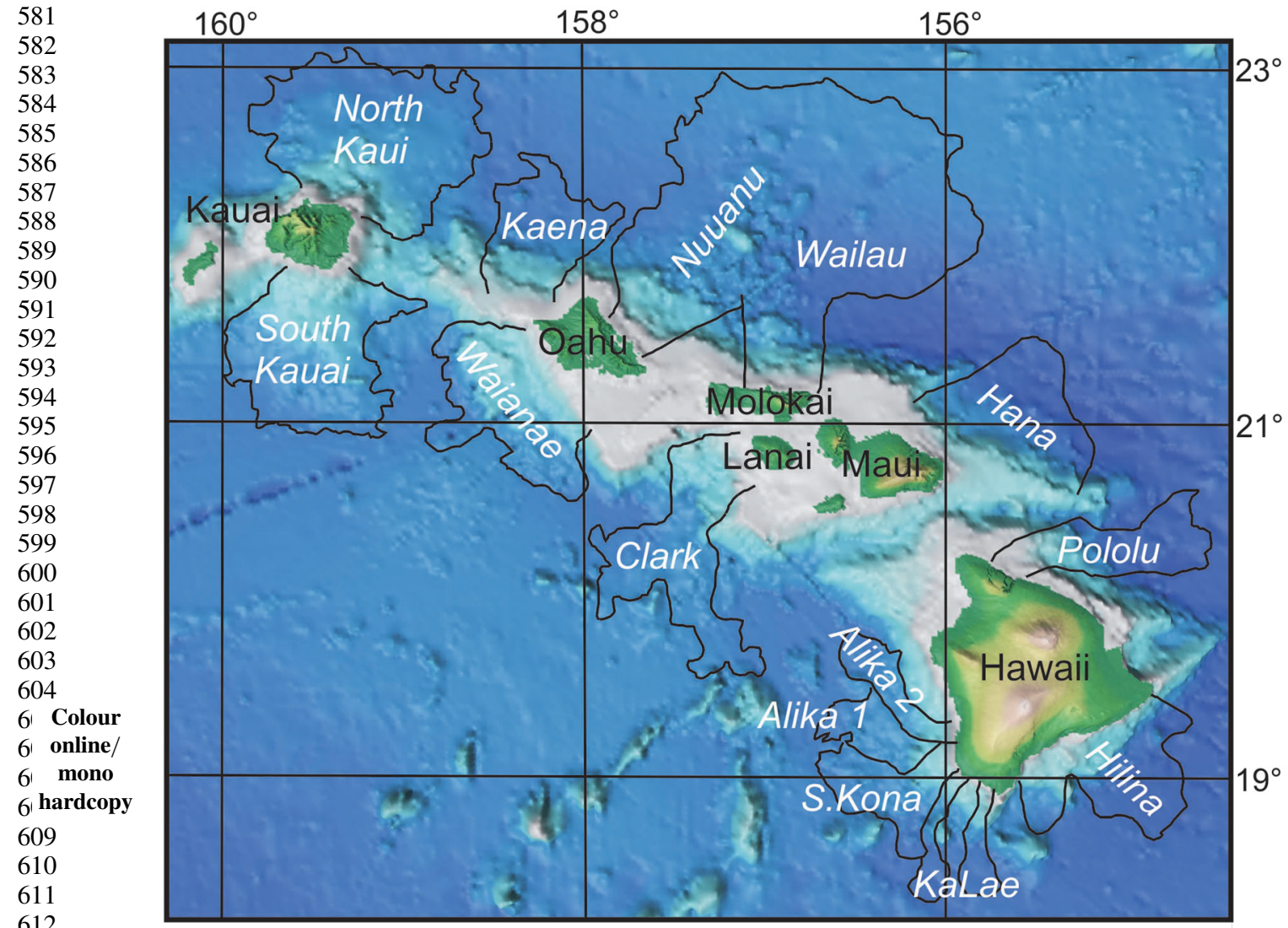

613

614

615

616

617

618

619

620

621

622

623

624

625

626

627

628

629

630

631

632

633

634

635

636

637

638

Fig. 5. Hawaiian seabed morphology ocations and extents of the Giant Submarine Landslides as mapped by EDQ2 Moore et al. (1989) (From Tappin, 2

EDQ3 mechanisms of failure (Piper et al. 1 Talling et al. 2007; Masson et al. 2009; Talling 2014) and very little published on their potential to generate tsunamis (Masson et al. 2006). Significant proven historical submarine landslide-generated tsunamis before 1998 include those of the Grand Banks in 1929 (Heezen \& Ewing 1952), Nice in 1979 (Assier-Rzadkiewicz et al. 2000; Dan et al. 2007) and Skagway in 1994 (Kulikov et al. 1996; Rabinovich et al. 1999). Both Nice and Skagway landslides were probably triggered by human impact, although the tsunami mechanisms are controversial. Both these events came sharply into focus after the PNG tsunami (Synolakis \& Bernard 2006). Other controversial events include the tsunami generated by the earthquake of 1946 in the Aleutians, where the $40 \mathrm{~m}$ local run-ups were most probably from a local submarine landslide triggered by the earthquake (Fryer et al. 2004; Okal \& Herbert 2007; von Huene et al. 2014). The 1945 tsunami in the Indian Ocean off Pakistan is a similar event to the
Aleutians in 1946 (e.g. Heidarzadeh et al. 2008), but no submarine landslide has been found or, indeed, even looked for. The tsunamis generated by the earthquake of 17 August 1999 at Izmit, Turkey are also probably associated with submarine landslides (Altinok et al. 2001).

The best-known historical submarine landslide tsunami before PNG was in 1929 on the Grand Banks, Canada but surprisingly considering the importance of the event, most $n$ se has been on the lands (d0.g. Piper \& Askt 1 7 7) and earthquake (e.g. Howa \& Kanimori 1987) and not the EDQ4 tsunami. Only one paper is published on numerical tsunami modelling of the submarine landslide (Fine et al. 2005), but this is based on a theoretical mechanism. The most significant prehistorical tsunami from a submarine landslide is Storegga which, because of the discovery of the Ormen Lange Gasfield, is also the best studied. Research on tsunamis generated from volcanic collapse has identified another submarine landslide mechanism, 


\section{R. TAPPIN}

analogous to clastic sedimentary events. However, volcanic collapse tsunamis, even those in the Hawaiian Islands, have not generated as much interest in their hazard to the same degree by which PNG raised the profile for non-volcanic submarine landslides. The exceptions are the Canary Islands landslides perhaps, which have had a consistently high media profile because of their potential to generate high-elevation, 'megatsunamis' in the far field, which could be a significant hazard to the east coast of the USA (Ward \& Day 2001; Gisler et al. 2006; Løvholt et al. 2008; Hunt et al. 2013 . Tehranirad et al. 2015). A point to note is that the Hawaiian collapses are submarine, whereas those in the Canary Islands are partly sub-aerial. Because of their retrogressive failure mechanisms however, which initiate on the seabed, the Canary Island collapses are included here. The Canary Island collapses are analogous to those of the Hawaiian volcanoes but smaller in volume which, together with their multistage, bottom-up collapse mechanisms proposed for the largest events such as those on Tenerife (Hunt et al. 2011), suggest that elevated tsunami wave heights could be more localized and concentrated near to source. Recent numerical tsunami modelling indeed suggests that, in the far field, frictional effects of propogation over the wide US coast shelf significantly reduces their onshore impact, although the volumes used in tsunami generation may be small (Tehranirad et al.
2015) and possibly underestimated (Simon Day, pers. comm., 2016)

\section{The impact of Papua New Guinea, 1998}

It was not until 1998 in PNG, when over 2200 people died in a tsunami now recognized as generated from an offshore seabed sediment failure (Kawata et al. 1999; Tappin et al. 1999), that the hazard from submarine landslide tsunamis was fully recognized (Bardet et al. 2003; Løvholt et al. 2015). The PNG event was the first investigated by a responsive programme of marine surveys (Fig. 6), and scepticism greeted the initial results (e.g. Geist 2000). The landslide architecture was constructed from the marine dataset, and for the first time used as the basis for realistic numerical models of tsunami generation (Tappin et al. 1999, 2001, 2008). Although the hazard from submarine landslides is now more generally recognized, the marine surveys required to map the submarine landslide hazard are expensive so only a few countries have so far carried these out to the degree necessary to fully identify the hazard (e.g. Grilli et al. 2009; ten Brink 2009; Clarke et al. 2014).

\section{How submarine landslides generate tsunamis}

Before PNG, simulations of tsunami generation were mainly confined to earthquake sources (Satake et al. 1996). Numerical earthquake tsunami-generation

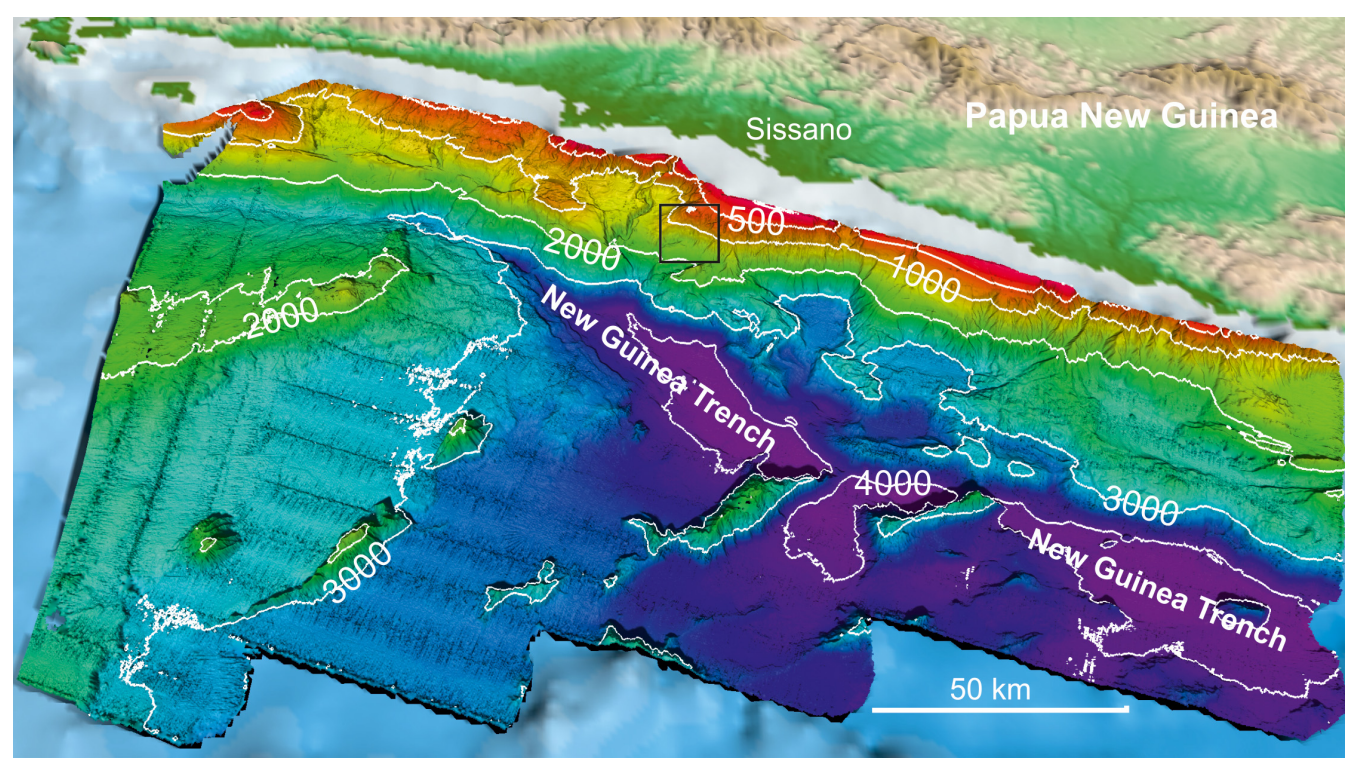

Fig. 6. Papua New Guinea regional bathymetry viewed from the north, showing the convergent margin in the foreground the Papua land mass to the rear. Depths in metres. Black square the location of Figure 7 (From Tappin, 20 


\section{IMPORTANCE OF GEOLOGY IN TSUMANI SCIENCE}

models are based on an assumption that the initial water surface deformation is instantaneous and equal to that at the seabed. For the rise time of most earthquakes, the long-wave phase velocity in the ocean is slow enough so that displacement can be considered instantaneous. There are slight modifications to the tsunami wave field for earthquakes of slow rupture duration (tsunami earthquakes). Seabed deformation is calculated from earthquake fault parameters using theoretical deformation models such as Okada (1985). Underwater landslides were considered to be ineffective at generating significant tsunamis because of their longer sourcegeneration times, smaller areas of seabed disturbance (compared to earthquakes) and the directivity of the tsunami produced (Hammack 1973; LeBlond \& Jones 1995; Geist 2000). Before the PNG event, one of the major challenges was in understanding how the relatively slow-moving submarine landslides generate tsunamis.

A further complication in understanding tsunamis generated by submarine landslides is the range of failure mechanisms which vary according to morphology, sediment type and/or kinematics (see Hampton et al. 1996; Turner \& Schuster 1996; Keating \& McGuire 2000; O'Grady et al. 2000). Theoretical numerical modelling of submarine landslides was visualized as a Bingham-type fluid flow, analogous to a translational mechanism, where large blocks disintegrated on travelling downslope to form turbidites (Hampton 1972; Geist 2000). Modelling of solid block landslides at the time of the PNG tsunami was in its infancy (Watts 1998). Submarine landslide failure is dependent mainly on sediment composition, which controls landslide morphology and kinematics. Numerical tsunamigeneration models were initially based on depthaveraged wave equations that represented immiscible liquids or water as a Bingham plastic (e.g. Jiang \& LeBlond 1992, 1994). While depth-averaging accurately applies to tsunami generation from earthquakes, it is questionable when applied to landslide tsunamis because it does not allow for vertical fluid accelerations, important during submarine landslide motion and tsunami generation (Grilli et al. 2002). In 1998, landslide constitutive equations used in modelling were largely untested by laboratory experiments or case studies (Tappin et al. 2008). Submarine landslide models were idealized, and not based on geological data. There was no established method of merging geological data with numerical landslide models. In total, there was little appreciation of the complexity of modelling tsunamis generated by the different submarine landslide mechanisms. All this was to change because of two major events: one prehistoric and thousands of years old, Storegga; and the other recent and devastating, Papua New Guinea in 1998.

\section{Submarine landslide numerical models}

Storegga $(8.5 \mathrm{ka} \mathrm{BP})$. The first realistic attempt at numerically modelling a submarine landslide based on a slide architecture from seabed morphology was Storegga (Harbitz 1992). Validation of the tsunami generated was from run-up recorded in coastal sediments deposited on the east coast of Scotland (Fig. 3; Dawson et al. 1988; Long et al. 1989) and uplifted lake sediments in the west of Norway (Svendsen \& Mangerud 1990). The landslide modelled was translational, moving at velocities of $20-35 \mathrm{~m} \mathrm{~s}^{-1}$ which were taken from measurements of the Grand Banks tsunami of 1929 (Heezen \& Ewing 1952). Three major slide events were modelled: the first and third as partially liquefied debris flows; and the second retrogressive failing from the bottom upwards. Individual slide volumes were between 1700 and $3880 \mathrm{~km}^{3}$. Average slide thicknesses used were between 88 and $114 \mathrm{~m}$. The recorded run-up heights of $4 \mathrm{~m}$ on the east coast of Scotland were best reproduced by slide velocities of $35 \mathrm{~m} \mathrm{~s}^{-1}$. The 1992 paper was a benchmark in tsunami numerical models as it was based on both a realistic landslide model and run-up data measured from sediments deposited on land. The numerical model was a major advance at the time, because only a few earthquake tsunamis had been simulated and the controls on tsunami generation by landslide architecture were not recognized. Submarine landslide tsunamis were only identified along two ocean margins: Storegga (Norway) and Grand Banks (Canada). In 1992, there were no numerical models of the Grand Banks tsunami.

Subsequent numerical models of Storegga postdated the PNG event (Bondevik et al. 2005a; Hill et al. 2014) and made significant improvements on the 1992 results of Harbitz as they were based on a more comprehensive dataset of geophysics and coring of the landslide (Bryn et al. 2005). The motivation to investigate Storegga was not the $8.2 \mathrm{ka} \mathrm{BP}$ tsunami, but to ensure that exploitation of the underlying Ormen Lange gas field would not create another hazardous submarine landslide similar to the 8.2 ka BP event (Bryn et al. 2005). Validation of later numerical models was based on a more extensive dataset of tsunami run-up data from Norway (Bondevik et al. 1997a, b), Faroe Islands (Grauert et al. 2001), Shetland Islands (Bondevik et al. 2003, 2005b) and mainland Scotland (Smith et al. 2004, 2007). With the later numerical models based on improved landslide architecture, maximum tsunami run-ups on the Shetlands increased to $20 \mathrm{~m}$ which agreed with new studies on the elevations of tsunami sediments on the islands (Bondevik et al. 2003). Sea levels were much lower when the Storegga landslide took place $(8.2 \mathrm{ka} \mathrm{BP})$ than at present. The sea-level curve for the Shetlands is 


\section{R. TAPPIN}

still uncertain, so these run-up elevations are most probably still underestimated.

The later numerical models of the Storegga tsunami also used a more comprehensive geotechnical and morphological dataset from the landslide (Forsberg 2002; Haflidason et al. 2005). These confirm that the Storegga failure mechanism was retrogressive, with large block failure initiated at the base of the slide at a water depth of $c .1000 \mathrm{~m}$. The time lag between the individual block failures as the slide retreated landwards is a major control on tsunami generation (Bondevik et al. 2005a; Løvholt et al. 2005). Tsunami run-up elevations from sediments preserved at the different locations constrains the timing of block slide development. The shape and volume of the modelled slide used by Harbitz (1992) were adjusted until they fitted the new and much more detailed slide reconstruction. Modelling of Storegga was not just to simulate the tsunami, but also to establish the slide mechanics and triggering (Kvalstad et al. 2005). In the revised slide model the maximum thickness $(400 \mathrm{~m})$ of the slide is near the upper headwall, gradually becoming thinner towards the slide front in the offshore direction. The slide volume generating the tsunami is estimated to be $2400 \mathrm{~km}^{3}$. The Storegga slide is probably the best studied of any tsunami from a translational-type failure mechanism.

Papua New Guinea tsunami (1998). The PNG tsunami struck during the initial development of the Ormen Lange gas field in 1998. PNG was an important precursor to the Indian Ocean tsunami of 2004 because the loss of life was greater than from any previous recent event. It resulted in a major revision in understanding of tsunami-generation mechanisms from submarine landslides; in this context it is second only in importance, although the generation mechanisms are different. Identifying the mechanism of the PNG tsunami required marine geophysical and geological data and, as with tsunami sediments, it utilized the expertise of geologists (Tappin et al. 1999, 2001, 2008). PNG also provided an important context to the identification of tsunamis from tsunami earthquakes (Kanamori 1972), where the associated tsunami is much larger than expected from the earthquake magnitude. It showed that although an earthquake might be small it might not be slow, and the tsunami mechanism could alternatively be from a submarine landslide. The discrimination between tsunamis generated by 'tsunami' earthquakes and submarine landslides is still uncertain, as initially suggested by Kanamori (1972) and further supported by events such as Java in 2006 (e.g. Kanamori 1972; Fritz et al. 2007).

The earthquake magnitude of the PNG event was small in comparison to the $10-15 \mathrm{~m}$ high tsunami that devastated the coast around Sissano Lagoon. It was not a 'tsunami' earthquake based on Newman \& Okal's $(1998 a, b)$ discriminant of E/M0 (E/M0 is the ratio between high-frequency energy $\mathrm{E}$ and low-frequency seismic moment M0), because it did not have the required 'slow' source characteristics. Several other aspects of the event also suggested the earthquake was not responsible for the tsunami. The aftershock distribution indicated a shallow-dipping thrust (McCue 1998; Hurukawa et al. 2003) rather than a steeply dipping event necessary to generate the recorded tsunami. The peaked run-up distribution along the coast suggested a local focused source rather than the broad source usually associated with an earthquake tsunami. The 20 minute time lag between the felt earthquake and the tsunami striking the coast did not agree with an epicentre located just offshore. The tsunami in the far field was very small and undoubtedly generated from the earthquake (Kikuchi et al. 1999), but it seemed unlikely that the local tsunami was from this mechanism.

All evidence therefore initially converged on a submarine landslide mechanism located close offshore. This conclusion was highly controversial (e.g. Geist 2000), so marine hydroacoustic and sampling surveys were required for confirmation. For the first time after a major tsunami, responsive marine surveys funded by Japan and the USA acquired a comprehensive hydroacoustic dataset with some sediment sampling off northern PNG (Tappin et al. 1999, 2001; Sweet \& Silver 2003). The hydroacoustic data comprised over $19000 \mathrm{~km}^{2}$ of multibeam bathymetry (Fig. 6), $4.2 \mathrm{kHz}$ highresolution, sub-bottom seismic lines (SBSL), and both single (SCS) and multichannel seismic (MCS) data. In the region of the landslide, four $7 \mathrm{~m}$ long sediment piston cores were recovered together with numerous shallow $(30 \mathrm{~cm})$ push cores of sediment, rock samples and marine organisms. Still and video photography of the seabed were acquired from a tethered remotely operated vehicle (ROV) and a manned submersible (MS).

Before the surveys, a translational landslide was proposed as the most likely tsunami mechanism (e.g. Geist 2000) and the first published numerical models were based on this mechanism (e.g. Heinrich et al. 2000). These numerical models successfully reproduced the recorded on-land tsunami elevation data, with the translational landslide treated as a fluid-like flow of a cohesionless granular material (Heinrich et al. 2000). From the marine surveys, however, this translational mechanism was shown to be unrealistic because seabed morphology and seismic data revealed a rotational slump (Fig. 7; Tappin et al. 1999). Theoretically, slumps by volume generate the largest tsunami (Tappin et al. 2008). At the time of the PNG tsunami, theoretical 


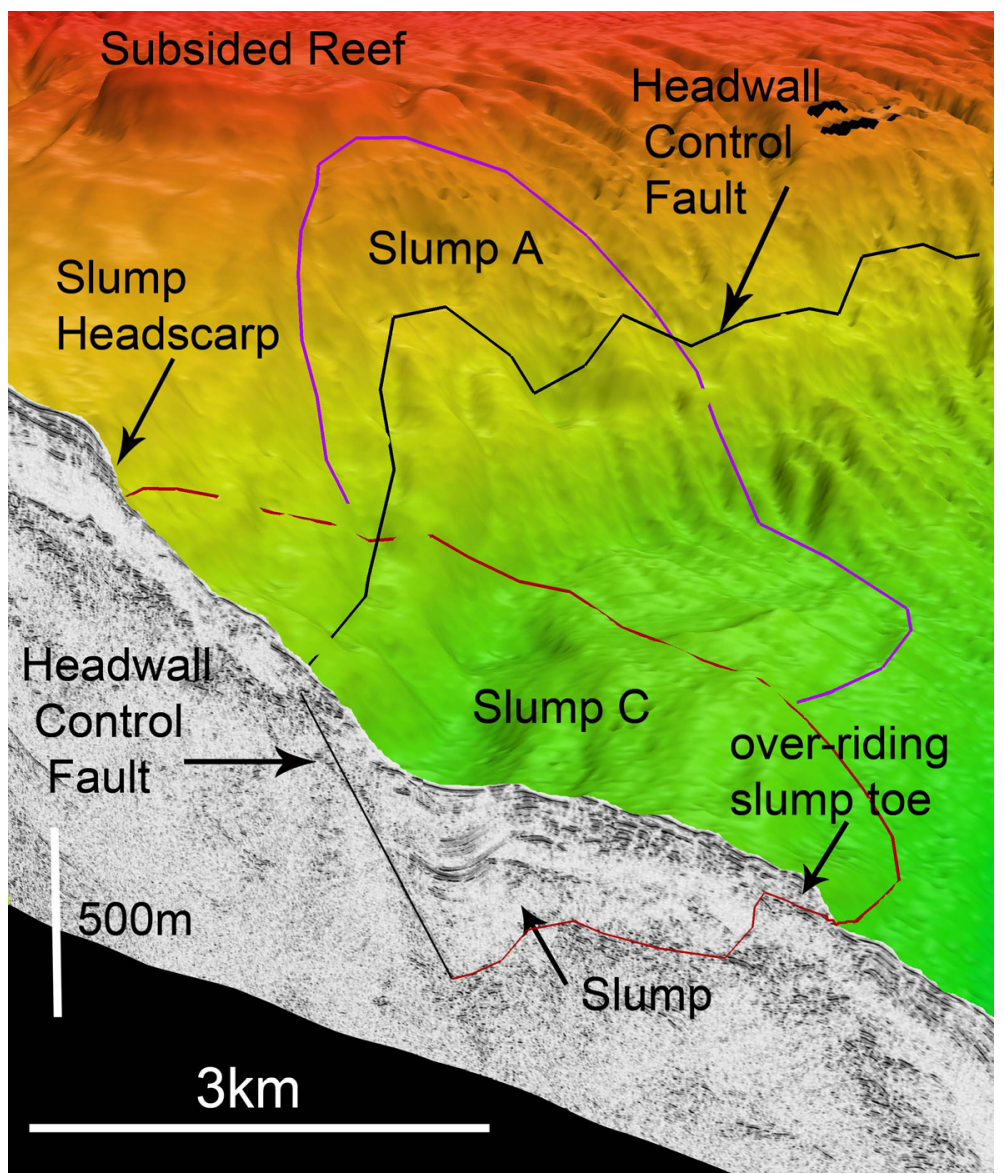

Fig. 7. 3D cutaway image of the PNG slump C that generated the 1998 tsunami, including a seismic section, viewed from the NE. Vertical exaggeration $\times 3$. Location shown in Figure 6 (from Tappin et al. 2008).

numerical models of tsunamis were based on: (1) sliding blocks (e.g. Watts 1997; Grilli \& Watts 1999); (2) finite volume discretization-volume of fluids (VOF) of the Navier-Stokes equations (Heinrich 1992); or (3) deformable landslides, with the generated waves governed by the finite volume discretization (Jiang \& LeBlond 1992, 1994).

To model the tsunami from the rotational slump, new numerical models were developed based on rotational failure with travel distance being limited $(800 \mathrm{~m})$ (Watts et al. 2003). The results showed that non-linear and dispersive tsunami propagation models were necessary to model submarine landslide tsunamis, with the shape and motion of a realistic submarine landslide wavemaker defined from marine survey data. This is unlike earthquake tsunamis where numerical wavemaker models are based on ground deformation from fault slip, derived from inversion of seismological, geodetic or tsunami observations (Okada 1985). To identify the landslide mechanism at PNG (see Tappin 201 multibeam echosounder (MBES) technology was used to map the detailed seabed morphology, the first time this had been attempted. The MBES data, combined with sub-seabed seismic, led to the construction of the submarine landslide architecture (Fig. 7) that underpinned the numerical wavemaker models. In addition, whereas earthquake rupture models are mainly defined by strike, dip and rake, the failure mechanisms of submarine landslides are many and varied as they are dependent on the nature of the sediment. As well as the differences in initial tsunami wave generation between earthquakes and submarine landslides, there are also significant differences in how their tsunamis propagate. Coseismic displacement from vertical seafloor deformation usually generates tsunamis with longer wavelengths and periods than those generated by landslides, because of their larger source area (Hammack 1973; Watts 1998, 2000). Coseismic 


\section{R. TAPPIN}

displacement generates tsunami amplitudes that correlate with earthquake magnitude (Hammack 1973; Geist 1998) except for tsunami earthquakes; submarine landslides produce tsunamis with amplitudes limited only by the vertical extent of centre of mass motion or the water depth (Murty 1979; Watts 1998).

The first numerical simulation of the PNG slump was devised at sea during the first survey in 1999; it was rudimentary, with many assumptions not validated. Initial tsunami-generation estimates were computed by hand, based on published (or soon to be published) literature (Watts 1998, 2000; Grilli $\&$ Watts 1999). The slump architecture was provisional because it was based only on the bathymetric data acquired during the survey (Tappin et al. 1999). The tsunami source used was a solid block two-dimensional (2D) underwater landslide (Grilli \& Watts 1999). It did not use depth-averaging; instead, it solved fully non-linear potential flow (FNPF) equations which allowed for vertical water acceleration. However, the tsunami propagation simulation used linear shallow-water wave equations. The maximum wave height of $6 \mathrm{~m}$ generated by the model was located offshore of the sand spit at the $10 \mathrm{~m}$ water depth contour. Although approximating the relative distribution of run-up along the coast, the maximum offshore water height was not of the same magnitude as run-up measured on land by the responsive surveys. Despite these shortcomings, the results were a major advance; not only was it the first time that a landslide-generated tsunami was modelled from a real event, but the modelling was based on MBES data. Comparison with the alternative earthquake-generation mechanism, which gave a maximum wave height at the shore of $2 \mathrm{~m}$ based on a shallow-dipping rupture mechanism, demonstrated that it was the slump rather than the earthquake that generated most of the local tsunami.

Subsequently, numerical models improved with the definition of slump architecture (Fig. 8) (Watts et al. 1999; Tappin et al. 2001). Most recent numerical modelling (Tappin et al. 2008) is from a slump modified from the marine survey data that included seismics (Fig. 7). Numerical modelling used an initial condition (wavemaker) using 'Tsunami open and progressive initial conditions system' (TOPICS) software that provides the vertical landslide displacements as outputs, as well as a characteristic tsunami wavelength $\lambda_{0}$ and a characteristic tsunami period $T_{0}$. To account for the dispersive nature of landslide tsunamis, the Boussinesq propagation models GEOWAVE (Watts et al. 2003) and the later development FUNWAVE (Tappin et al. 2008 ) were used. The initial numerical models provided tsunami wave elevations offshore, not on-land run-ups, and the later modelling provided tsunami wave elevations at the coast. This was a significant improvement over earlier simulations using tsunami source and (non-dispersive) shallow-water, wave tsunami propagation models (see discussion in Tappin et al. 2008).

\section{Raised awareness after PNG 1998 event}

The great loss of life from the PNG tsunami and the demonstration of the non-earthquake mechanism from numerical models were a catalyst to an intense period of research on how submarine landslides generate tsunamis (Synolakis \& Bernard 2006). Recognition of the submarine landslide hazard in tsunami generation resulted in increased awareness of these events but also that there were no comprehensive models that covered all aspects of landslide-induced tsunamis from source mechanism, through propagation to coastal inundation. Before the identification of the submarine landslide mechanism of the PNG tsunami, understanding of the mechanics of landslide tsunamis was lacking. After the PNG event, there was a re-evaluation in the USA of other possible submarine landslide events such as Palos Verdes, California (Fig. 9) where the under-prediction of the height of the leading wave led to the dismissal of the local tsunami hazard. PNG also led to the resolution of the dispute concerning the landslide trigger of the 1994 Skagway, Alaska tsunami (Synolakis \& Bernard 2006). Marine geophysical data now reveal that submarine landslides are common along most continental margins (Fig. 9), especially those of California, Oregon and the east Coast of the USA. As a result, the level of hazard posed by relatively moderate earthquakes and submarine landslides was re-examined (e.g. Borrero et al. 2001, 2004). There was an increased recognition, by both the scientific research and tsunami forecasting communities, that earthquakes affecting oceanic margins frequently trigger submarine landslides (e.g. Geist et al. 2009; Grilli et al. 2015). Although many of these might not be tsunamigenic in the far field, they had the potential to generate significant local tsunamis, even if the earthquake magnitude was small and not of a sufficient magnitude to generate a significant coseismic event.

Once the landslide mechanism became evident, one of the first responses to the PNG tsunami was the workshop on landslide tsunamis sponsored by the National Science Foundation at the University of Southern California on 10-11 March 2000. The resulting special publication (Bardet et al. 2003) recognized that landslide tsunamis require multidisciplinary studies that build upon experience in engineering seismology, geotechnical engineering, marine geology, modelling of sediment deposition 
9 hardcopy

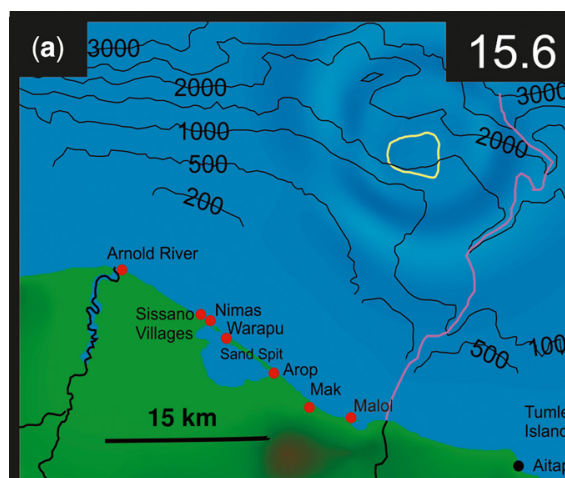

(b) 3000

18.6

(c) 3000

20.1

(d)
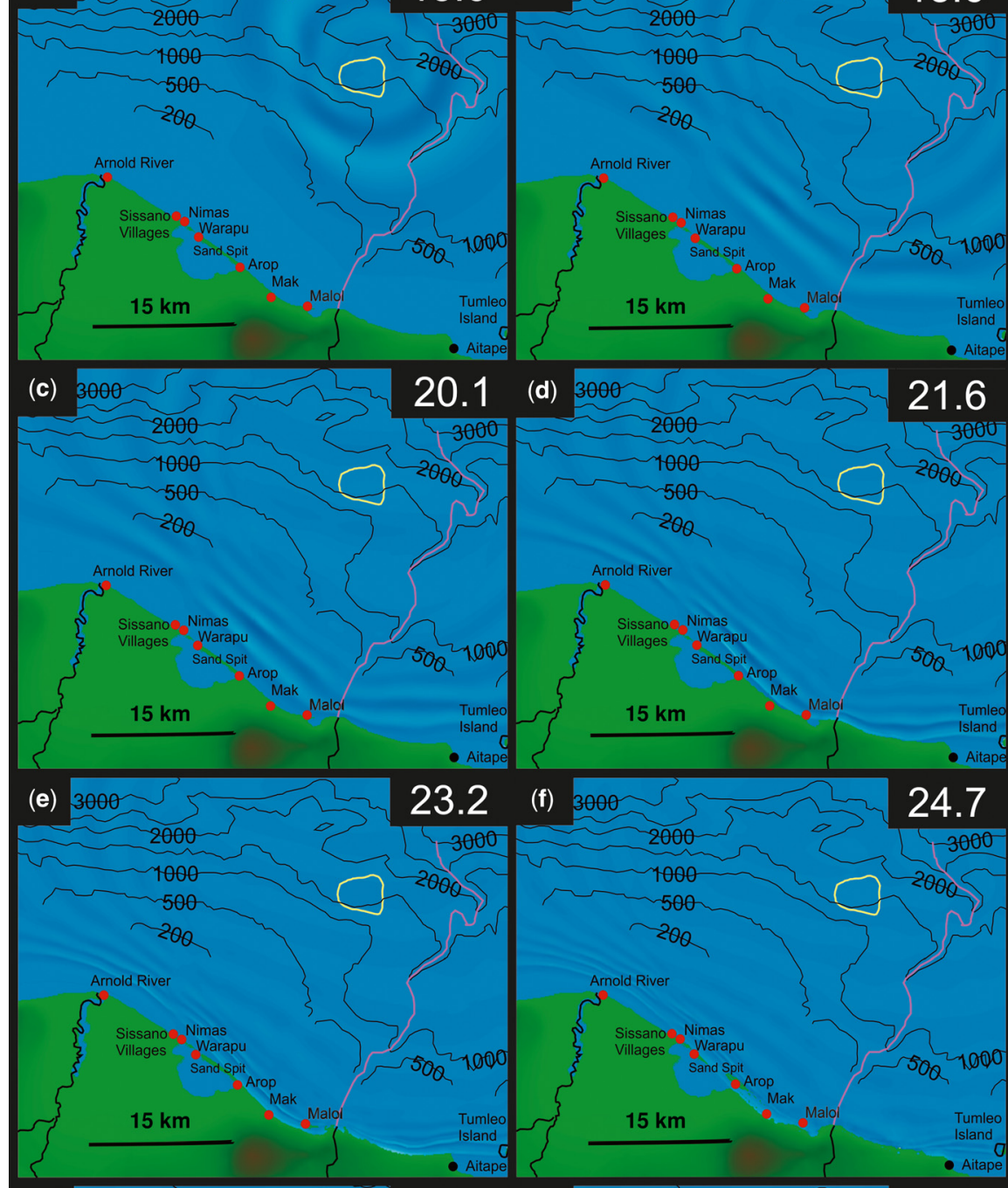

23.2

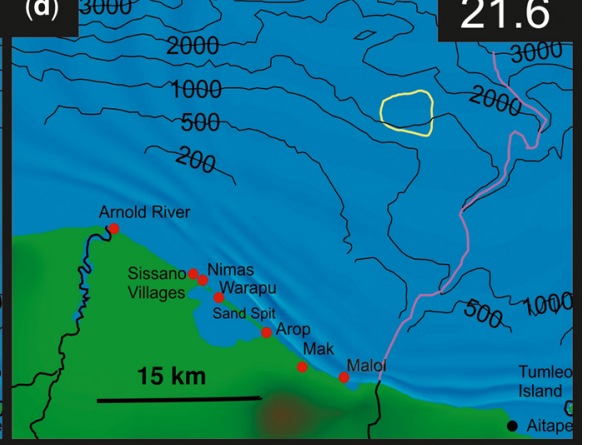

\section{2}
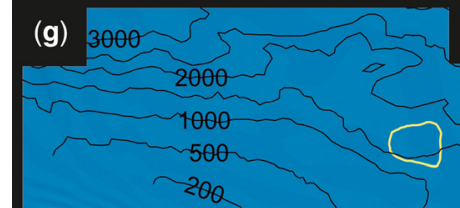

26.2

(h)

(f) 3000
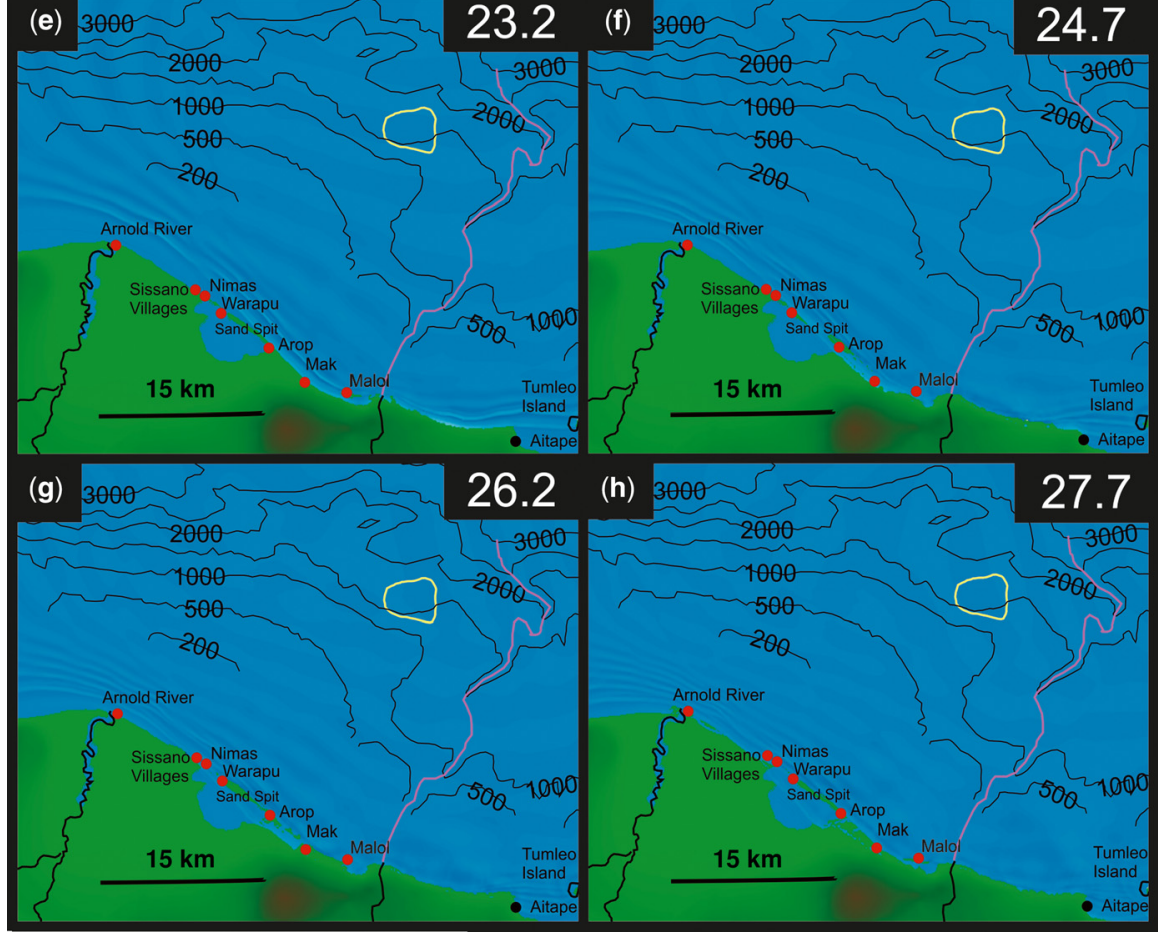

Fig. 8. Eight snapshots of Papua New Guinea, 1998 tsunami propagation and inundation from a slump source. Light blue are elevation waves and dark blue are depression waves. Numbers in the top right of each image are the tsunami propagation times after the main earthquake shock trigger. The slump location is in yellow (from Tappin et al. 2008). 


\section{R. TAPPIN}

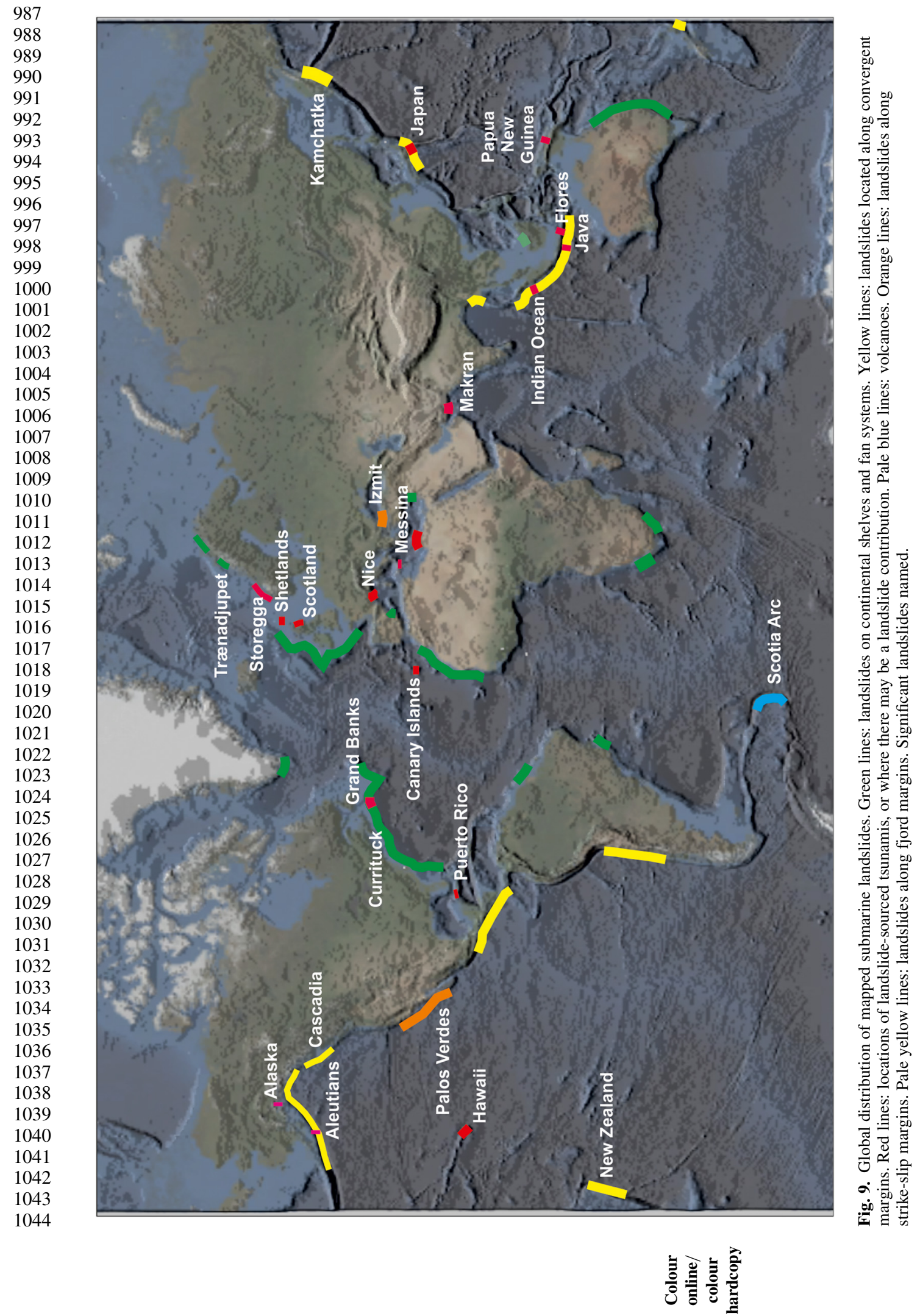




\section{IMPORTANCE OF GEOLOGY IN TSUMANI SCIENCE}

and run-off, and hydrodynamics. Another special publication (Tappin 2007) focused on tsunami sediments. In approximately $35 \%$ of all tsunami events studied, nearshore waves from landslide tsunamis could exceed those resulting solely from coseismic ground motions (Watts 2004). In the USA, submarine landslide research programmes resulted in a special issue of the journal Marine Geology focused on the tsunami hazard along the east coast of the US (Chaytor et al. 2009; Geist \& Parsons 2009; Grilli et al. 2009; Lee 2009; ten Brink 2009; ten Brink et al. 2009; Twichell et al. 2009).

Later tsunami landslide research made some significant counterintuitive discoveries. One of the most fascinating was that along the passive margins of the North Atlantic (Fig. 9) the majority of potentially tsunamigenic submarine landslides were found to occur on seabed slope angles of less than $5^{\circ}$, with some of the largest slides failing on slopes of less than $1^{\circ}$ (Hühnerbach et al. 2004). This evidence on slope failure resulted in considerable conjecture on how submarine landslides fail (Canals et al. 2004; Smith et al. 2013; Talling et al. 2014). Subsequently, there has been a large amount of physical and numerical modelling work devoted to studying tsunamis generated by submarine landslides (e.g. Heinrich 1992; Grilli \& Watts 1999, 2001, 2005; Watts 2000; Tinti et al. 2001; Ward 2001; Grilli et al. 2002; Lynett \& Liu 2002; Enet et al. 2003; Watts et al. 2003, 2005; Locat et al. 2004; Enet \& Grilli 2005, 2007; Fine et al. 2005; Haugen et al. 2005; Liu et al. 2005; Abadie et al. 2012; Ma et al. 2013, 2015; Løvholt et al. 2015; Smith et al. 2016).

\section{Improved understanding after Japan 2011 event}

Up until March 2011, PNG remained the only proven catastrophic tsunami generated by a submarine landslide. There were suspicions of a submarine landslide contribution to other events including Java, 2006 (Fritz et al. 2007) and the highly focused tsunami at Riangkroko, Flores Islands in 1992, where coastal (sub-aerial) landslides were the probable cause (Yeh et al. 1993). Without marine surveys at these locations, their proposed submarine landslide tsunami-generation mechanisms remain unresolved. It was not until the Japan tsunami of 11 March 2011 that exceptionally high $(40 \mathrm{~m})$ and focused run-ups along the Sanriku coast on northern Honshu Island, north of the main earthquake rupture, suggested another submarine landslide event in addition to the magnitude $M_{\mathrm{w}} 9$ earthquake (Tappin et al. 2014). Two important aspects of this event suggested a second tsunami mechanism in addition to the earthquake. Firstly, the numerical tsunami simulations from earthquake mechanisms could not reproduce the elevated $(40 \mathrm{~m})$ wave elevations recorded along the coast between latitudes $39^{\circ} 30^{\prime}$ and $40^{\circ} 15^{\prime} \mathrm{N}$ (e.g. Fujii et al. 2011). Secondly, even when inverting tsunami waveforms and using dispersive-wave Green's functions, the simulations could not satisfactorily reproduce the timing and high-frequency content of tsunami waveforms recorded at the nearshore GPS buoys located in this area, nor the timing and dispersive-wave train at the Deep-Ocean Assessment and Reporting of Tsunamis (DART) buoy \#21418 located $600 \mathrm{~km}$ off the coast (Gusman et al. 2012; Iinuma et al. 2012; Løvholt et al. 2012; Romano et al. 2012; Grilli et al. 2013; Satake et al. 2013; Yamazaki et al. 2013). These deficiencies were identified by comparison of the tsunami mechanisms from ten earthquake source models, obtained by inverting seismic and geodetic data and tsunami waveforms (see MacInnes et al. 2013, fig. 4). This comparison found that none of the mechanisms satisfactorily reproduced the elevations of the recorded run-ups on the Sanriku coast north of latitude $39^{\circ} 00^{\prime} \mathrm{N}$.

Marine hydroacoustic data of the type previously used to identify seabed failure elsewhere (such as PNG) were available in the region of the Japan earthquake; the area off Honshu Island had been mapped by MBES both before and after the tsunami. From these data, and a limited number of seismic lines, the presence of submarine landslides offshore of the elevated Sanriku run-ups was confirmed (Fig. 10). In addition, in the region of the earthquake there were offshore bottom sensors which recorded the frequency content of the tsunami waveforms. This was the first time that these marine seabed data were available to record a tsunami generated by a large-magnitude earthquake. Analysis of these data provided the potential to discriminate between different tsunami mechanisms, because the wave frequency content of tsunamis from earthquakes and submarine landslides are quite different. Since the wave frequency content of tsunamis from earthquakes is much lower than from submarine landslides, it could be used to identify the submarine landslide location and to validate the numerical tsunami models.

Although a submarine landslide was the most likely second tsunami mechanism, an alternative was out-of-sequence (splay) faulting. There was no evidence for the splay faulting in the published seismic profiling data for the source region (Tsuru et al. 2002); however, there was considerable evidence supporting a submarine landslide. Large slumps had been found on the margin of the accretionary prism off the Sanriku coast (Cadet et al. 1987; von Huene et al. 1994; Tsuru et al. 2002). Data from two ocean bottom pressure gauge stations 


\section{R. TAPPIN}

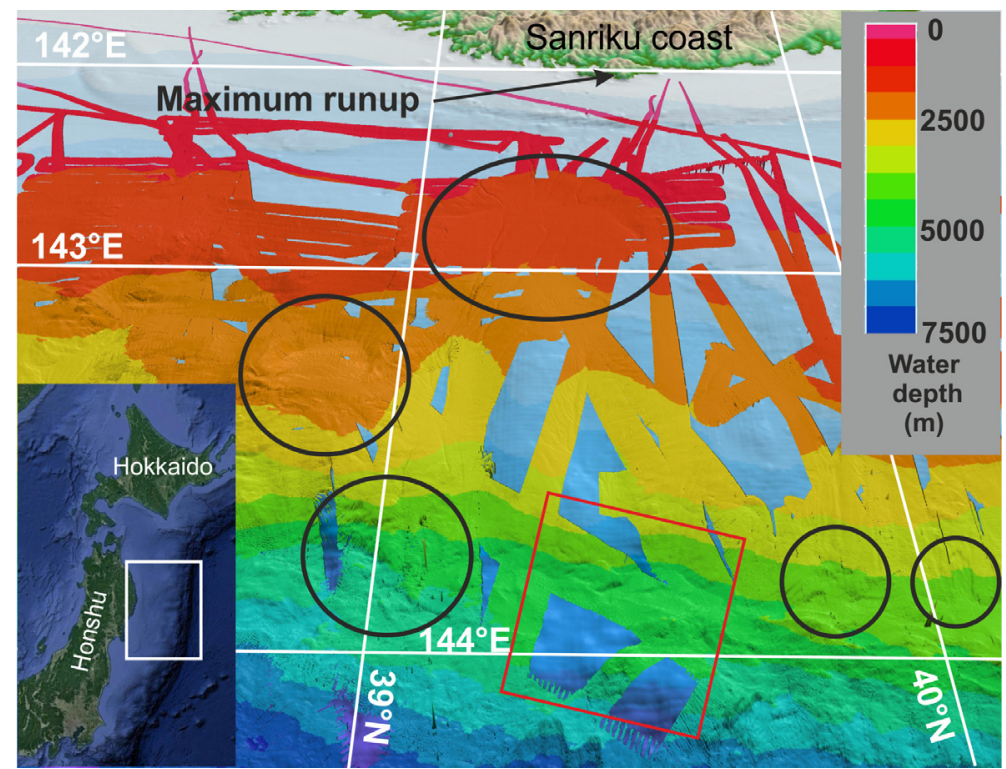

Fig. 10. Japan, 2011. Submarine landslides (black circles/ellipses) in the region off northeastern Honshu Island from bathymetry, viewed from the east. Red square: the location of the landslide triggered by the March 2011 earthquake. Highest elevation observed tsunami run-up/inundation (around $39.5^{\circ} \mathrm{N}$ ) along the Sanriku coast is also marked. Approximate location of this figure shown in inset (From Tappin et al. 2014).

TM1 and TM2 off Kamaishi (latitude $39^{\circ} 12^{\prime} \mathrm{N}$ ) indicated that at least part of the tsunami source in this region is a narrow area in the deeper part of the Japan Trench (Maeda et al. 2011). Seabed movement had been identified in the area of earthquake rupture from before and after bathymetry (Kawamura et al. 2012), but this was south of the region of elevated onshore run-ups. Backward ray tracing using the higher-frequency, leading elevation wave from the tsunami recorded by the seabed buoys located offshore of the region of high run-ups identified the most likely location of a submarine landslide that could have generated these. Within this area, north of that identified by Kawamura et al. (2012), a number of submarine landslides were identified from bathymetry acquired from before and after the earthquake (Tappin et al. 2014). There were few seismic data in this region and none at the location identified by the ray tracing as the potential additionary tsunami source, so subseabed structure was not available to confirm this interpretation. A slope stability analysis confirmed that earthquake shaking could have triggered the landslide. Numerical modelling of a dual earthquake and submarine landslide tsunami mechanism (Fig. 11) demonstrated that in combination they reproduced the waves recorded along the Honshu coast, especially in the north of the inundated area in the Sanriku region (Tappin et al. 2014).

\section{Undefined hazard}

Extensive mapping of continental shelves reveals the common presence of submarine landslides, although large regions remain unmapped (Fig. 9). At present however, only four significant submarine landslide tsunamis have been mapped, modelled and validated: Storegga, Grand Banks, PNG and Japan (two of which have led to a significant loss of life). For volcanoes, only the flank collapse of Alika 2 on the Big Island of Hawaii is well studied; the tsunamis from the Canary Island volcanoes remain controversial.

Regarding passive margins, the best-studied region is the North Atlantic (Fig. 9). Here, the general controls on landslide failure are related to climate-controlled influences on sedimentation during glacial and interglacial periods (e.g. Lee 2009; Talling et al. 2014), with earthquakes being the most likely triggering mechanism. The specific relationships between climate and landslide failure are still far from clear, however (Urlaub et al. 2013; Talling et al. 2014). Storegga is well studied in the NE Atlantic, and the associated tsunami was elevated along the surrounding coasts and geographically extensive. There is still no evidence for tsunamis from the other large-volume landslides off Norway (such as Trænadjupet; Fig. 9) located north of Storegga. Further south in the Shetlands 
1181

1182

1183

1184

1185

1186

1187

1188

1189

1190

1191

1192

1193

1194

1195

1196

1197

1198

1 ก Colour

1. online/

1. mono

1 hardcopy

$1 \angle 03$

1204

1205

1206

1207

1208

1209

1210

1211

1212

1213

1214

1215

1216

1217

1218 (a)

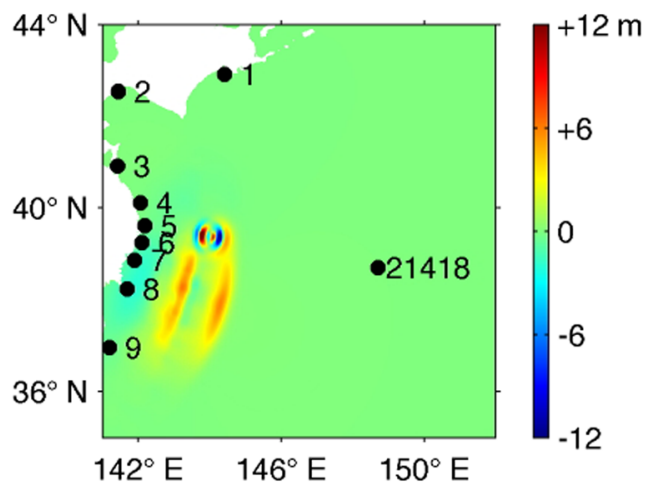

(c)

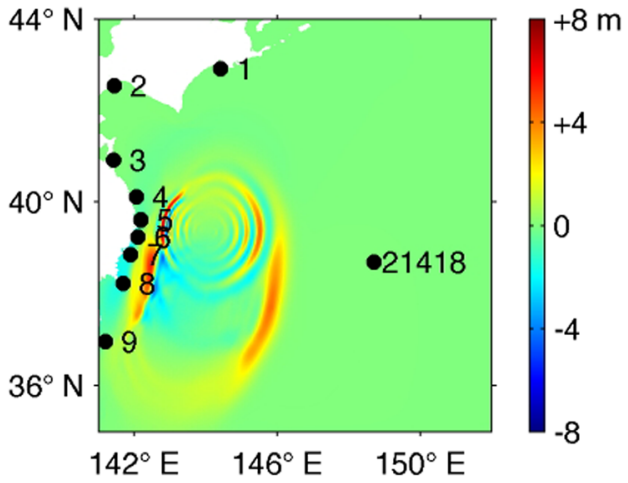

(e)

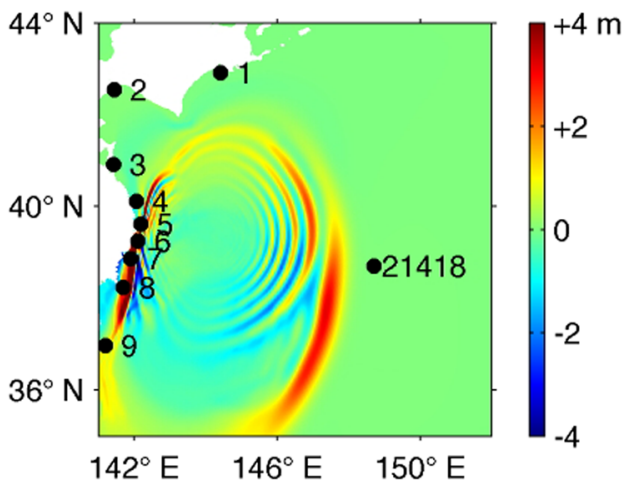

(b)

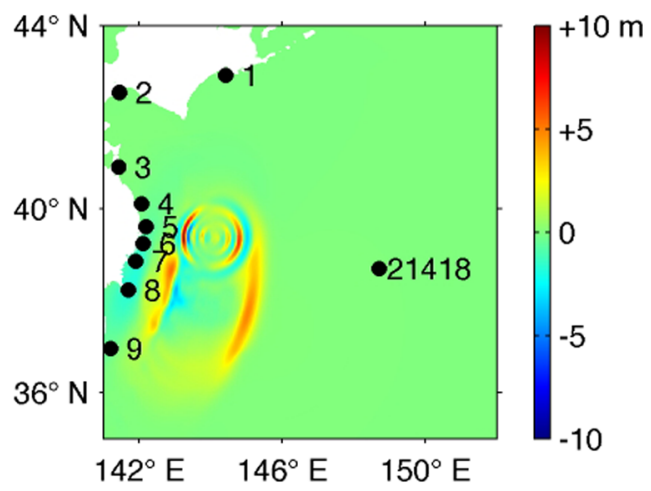

(d)

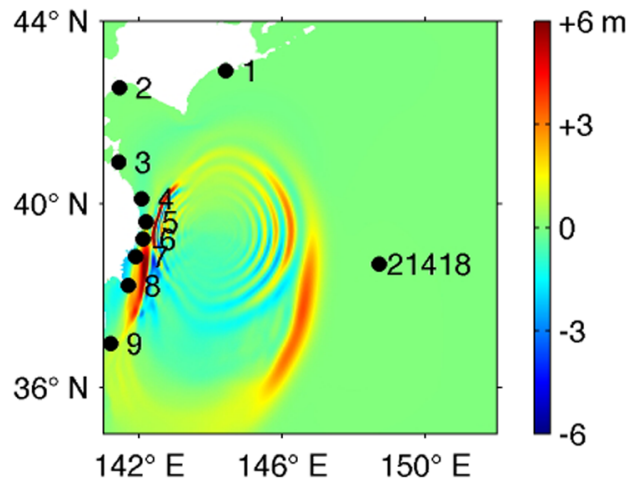

(f)

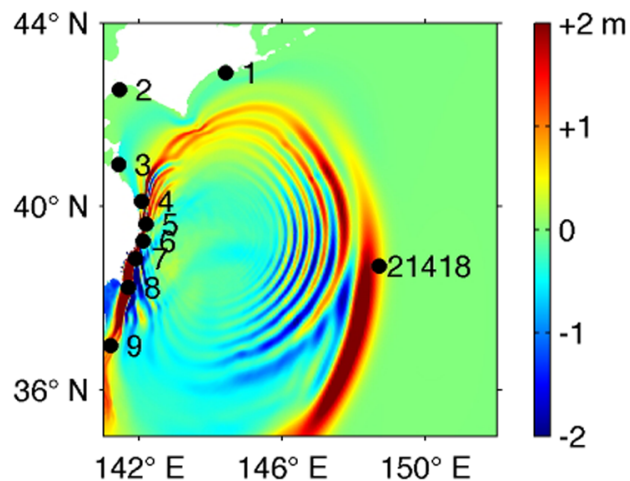

Fig. 11. Japan tsunami, 2011. Numerical simulation of the 2011 tsunami using a dual earthquake and submarine landslide source mechanism, showing instantaneous surface elevations at time (a) 5, (b) 10, (c) 15, (d) 20, (e) 25 and (f) $30 \mathrm{~min}$. Labelled black dots mark the locations of GPS buoys and of DART buoy \#21418. Note the highly dispersive nature of waves generated by the SMF source to the north, as compared to the longer-wavelength, long-crested, non-dispersive earthquake-generated tsunami waves to the south (From Tappin et al. 2014).

(Fig. 9) there are tsunami sediments much younger than Storegga, dated at 1.5 and $5 \mathrm{ka} \mathrm{BP}$ (Bondevik et al. 2005b), but there is no obvious tsunami mechanism for these events except the possibility of submarine landslides. The most likely location for the landslides is off Norway, for example Trænadjupet where two events are recognized, but the ages of these were dated at 3-5 ka BP and 19-22 ka BP 
121 EDQ5 (Laberg \& Voren 2000), that is, different from the 1220 Shetland events. The mechanisms for the Shetland 1221 sediments therefore seem to be more local, but are 1222 yet to be found. ence and distribution of such a large number of submarine landslides, some of significant volume, identifies a potential risk from their associated tsunamis (although statistical analysis suggests the risk is small; Grilli et al. 2009). Further research is required because the coast is densely populated and nuclear power plants are present (ten Brink et al. 2014). The tsunami hazard is mainly from submarine landslides rather than earthquakes (ten Brink 2009; ten Brink et al. 2014).

The only other country where there has been a concerted marine programme on a passive margin is Australia where, off the east coast, MBES mapping reveals a large number of landslide scars offshore of significant concentrations of population (Fig. 9) (Clarke et al. 2014). Numerical modelling suggests that the hazard here may be limited, however (Webster et al. 2016).

Along convergent margins, the hazard from submarine landslide tsunamis may be much greater than along passive margins. PNG is the best-known and most comprehensively researched submarine landslide tsunami along a convergent margin. Japan follows as a close second, although further confirmation is required to locate the exact position of the submarine landslide. Other convergent margin tsunamis where there is a possible landslide component include those of Messina (1908), Makran (1945), Aleutians (1946), Alaska (1964), Puerto Rico (1918), Flores Islands (1992) and Java (2006) (Fig. 9). One of the most devastating historical, convergent-margin tsunamis was Messina, 1908 (Fig. 9). A total of 50000 people died in the earthquake from collapsed buildings in Messina and Calabria with a large, but uncertain, number drowned in the ensuing tsunami. Over 600 people died in the Java tsunami and 1000 at Flores, where the highly focused tsunami flooded up to $25 \mathrm{~m}$ above sea level. There is a hazard programme off NW USA similar to that on the east coast, established for dual earthquake and submarine landslidegenerated tsunami along convergent margins. This programme recently re-evaluated the Aleutian tsunami of 1946 because of the controversy over the submarine landslide mechanism of the local $40 \mathrm{~m}$ high tsunami (Fryer et al. 2004; López \& Okal 2006; Locat et al. 2009). Re-evaluation based on MBES and seismic data (von Huene et al. 2014) now identifies the landslide location previously proposed by Fryer et al. (2004), but this has yet to be numerically modelled. For most of the convergentmargin tsunamis identified above, the submarine landslide contribution remains uncertain because not all have marine survey data on which to evaluate the seabed for landslides that can underpin numerical tsunami models. Hydroacoustic data have been used to identify submarine landslides for the Aleutians, Alaska, Messina and Puerto Rico events (Fig. 9) and re-evaluate their tsunami hazard.

\section{Discussion}

The numerous tsunamis experienced since 1992 suggest that we are living in a period where these events may be more frequent than previously. Recognition of this (apparent) high frequency and concomitant hazard has resulted in a greater awareness of the tsunami impact, which requires better understanding so the hazard and risk can be fully addressed on a sound scientific basis. An improved understanding of the hazard and risk will necessarily require a continued geological input. A major requirement in hazard mitigation is for longer-term 


\section{IMPORTANCE OF GEOLOGY IN TSUMANI SCIENCE}

records so that the frequency of tsunami events can be better understood. This longer-term record can only be gained from the sediments laid down as tsunamis flood the coast. Geologists, as the arbiters of this record, can contribute based on major advances resulting from the recent catastrophic events of PNG (1998), the Indian Ocean (2004) and Japan (2011). Tsunami sediments provide a longer-term record for tsunami impact. Together with improved understanding of inundation limits from new methodologies (such as geochemistry), the impacts of older historical and prehistorical tsunamis and their generation mechanisms can be revised as in Japan with the Jogan (869) event. Based on recent events, where tsunami hydrodynamics are recorded and the origin of the sediments established, tsunami sediment can again be used through novel inverse modelling methodologies of tsunami flow speeds and depths to better understand older events at the same locations. This methodology also has potential in regions where there are no observed recent events, but where there is a historical or prehistorical record. Inverse modelling of tsunami sediment inundation provides new insight into generation mechanisms and magnitudes.

Although earthquakes are undoubtedly the most frequent mechanism of tsunami generation, two events (PNG and Storegga) indicate that submarine landslides are a secondary but important hazard. These latter events were recognized and researched over a similar period of time in the late 1990s to early 2000s; one (Storegga) was prehistoric so had little human impact, and the other (PNG) was very recent, killing over 2200 people. The recognition of the Storegga tsunami was from a coeval relationship between the tsunami sediments discovered in Scotland and a submarine landslide off the Norwegian coast, with the identification of the sediments motivating the first numerical modelling. The discovery of the Ormen Lange Gas field in 1997 led to a major investigation into slope stability and tsunami generation. When the PNG tsunami struck in 1998 and the landslide mechanism was identified, the Storegga gas field developers recognized its importance. Storegga and PNG remain the beststudied and validated examples of landslidegenerated tsunamis. The reasons for their study are entirely different. At Ormen Lange, the imperative was to prove that exploitation of the gas field would not trigger another tsunami. With PNG, the scale of the loss of life and initial uncertainty in the generation mechanism dictated that the cause of the tsunami had to be understood. Unlike Storegga, where oil money was available to fund a comprehensive investigation of the landslide, with PNG there was no obvious donor to fund the marine surveys which were organized on humanitarian grounds. In both instances, geologists made major contributions both to understanding tsunami generation and validation of numerical models. PNG was the first recent event where there was a focused post-event marine survey organized and managed by geologists. For Storegga, the numerical models were based on marine data and validated by sediments deposited by the tsunami on adjacent coastlines. For PNG, although the tsunami sediments were analysed and in fact used as a basis for the first inverse modelling, the numerical models were validated from tsunami run-up elevations acquired during post-event surveys.

Although only four (five with Alika 2) significant tsunamis are positively identified as generated by submarine landslides, seabed mapping of continental shelves reveals their ubiquity (Fig. 9). Too few landslides are yet dated, and even fewer studied to a degree necessary to understand the controls on their generation. These controls on sediment failure and landslide frequency are therefore poorly understood, so the hazard from submarine landslides remains undefined. Recent studies suggest that submarine landslide failure is random (e.g. Urlaub et al. 2013), but there are still too few events studied in sufficient detail or accurately dated to be certain of this. Urlaub et al. (2013) analysed 68 events, 50\% of which they were unable to date to sufficient resolution to relate to potential landslide controlling factors. Because the onds on failure are complex (Tappin 2009, 201 alling 2014) more events require researching before reliable conclusions can be drawn on the most important failure mechanisms. Recent overviews (ten Brink et al. 2016) suggest that as more events are studied, improved understanding of landslide failure and triggering mechanisms, particularly in specific tectonic environments, will result. Although earthquakes are still the most likely landslide triggers, these may not only be 'tectonic' in the context of convergent margin environments. There are also strong climate controls on earthquake rupture, for example in high latitudes due to glacioisostatic processes, such as established from research on Storegga (e.g. Bungum et al. 2005). In addition, new research suggests there may be triggering relationships between earthquakes and continental shelf loading from sea-level rise not previously recognized (Brothers et al. 2013; Smith et al. 2013). Regarding tsunami generation, most submarine landslides have the potential to generate hazardous events if of sufficient volume. The preservation potential of tsunami sediment is low; so, even though evidence for tsunamis associated with the landslides may be absent, this may not necessarily discount tsunami generation.

The Japanese tsunami of March 2011 led to the confirmation that tsunami sediments were critical in identifying inundation limits. It revealed that submarine landslides are an additional, yet unforeseen, 


\section{R. TAPPIN}

major hazard even where a large-magnitude earthquake generates a devastating tsunami. It also demonstrated the importance of new technologies, such as seabed pressure sensors and improved geological (geochemical) methodologies, in the identification and discrimination between tsunami mechanisms and their coastal impact.

Challenges remain in improving our understanding of tsunamis and their hazard, to which geologists can contribute. The disintegration of translational landslides, and how this controls tsunami generation, has yet to be fully addressed by numerical models, which need to be more complex to be realistic. Geologists can contribute in developing more realistic landslide models from marine data and in their validation from sediment data. A major challenge is in determining the hazard from tsunamis generated from volcanic eruption, which is hardly researched. There have been some theoretical studies (e.g. Pareschi et al. 2006; Novikova et al. 2011), but these have not been validated. Even validated studies leave uncertainties over mechanisms (e.g. Ulvrova et al. 2016), however. There are numerical models of small-scale events, such as from Montserrat (Pelinovsky 2004), but their relevance to large-scale eruptions is uncertain. It is almost certain that, as with recent events such as the Indian Ocean, Japan and PNG where the seminal research has resulted from a catastrophe, the challenge of eruption tsunami mechanisms will be met only in response to a future major event with significant loss of life and/or major economic impact. The most recent (and only) catastrophic eruption tsunami in 1883 was when Krakatau in the Java Strait exploded, devastating surrounding coastlines and killing 36000 people. To understand the eruption tsunami mechanism demands validated numerical models and, fortunately, Krakatau was subject to the first post-event tsunami survey ever carried out (Verbeek 1885). Although there was an immediate response to the tsunami impact, and the volcanic eruption has been well studied (e.g. Self \& Rampino 1981), there is still uncertainty over the final cataclysmic explosion during which the devastating tsunami was generated. Alternative possible tsunami mechanisms include pyroclastic flows, caldera collapse or both as a dual mechanism (Francis 1985). There is only one comprehensive numerical modelling study, and this supports the entry of pyroclastic flows into the sea (Maeno \& Imamura 2011). The results are however questionable because of the validation used. Globally, there are 42 volcanoes similar to Krakatau which could erupt with similar consequences. The uncertainty over the tsunami mechanisms of eruption therefore remains an important issue that needs addressing if appropriate mitigation and response strategies for eruption tsunamis are to be developed, similar to those for earthquakes and submarine landslides.

\section{Conclusions}

Over the past 30 years, there have been major advances in understanding the mechanisms of tsunami generation and tsunami impact. Improvements in technology, documentation of events and ability to model them have largely been because of devastating events. For the past 20 of these 30 years many of the advances have been by contributions from geology and by geologists. Most now-accepted ideas, such as that tsunamis lay down sediment when they flood the land and that submarine landslides generate hazardous tsunamis, were at first controversial and considered unlikely. Now, postevent surveys acquire geological data as a matter of course. Earthquakes are undoubtedly the primary tsunami mechanism, but improved understanding of earthquake mechanisms, magnitudes and frequencies in tsunami generation result from research on their associated tsunami deposits. Studies of prehistoric tsunami sediments have resulted in timescales now extended back in time for thousands of years, beyond historical records. These extended records have improved the understanding of the frequencies of these events that together allow improved mitigation and response strategies. Comparison of sediments from recent tsunamis with those preserved in geological records at the same locations offers the opportunity to better understand past events. Recent major advances in inverse modelling of earthquake tsunami magnitudes from sediments indicate their potential in this field.

Understanding tsunami generation from landslides, especially submarine events, is underpinned by geological research in mapping the locations and architectures to identify failure mechanisms and then using these mechanisms for realistic numerical simulations. Whereas the hazard from submarine landslide tsunamis is now recognized, the extent and risk from these events is still uncertain. Submarine landslides are present along the margins of most continents; many of these margins remain largely unmapped however, so their hazard is not known.

Eruption-generated tsunamis remain poorly researched, and their mechanisms are not well understood. Their global extent requires more focused programmes of research to address their hazard and risk. Based on the most recent history of scientific advance for earthquake and landslide tsunami, it may well be that advances in understanding eruption events await the next catastrophic event. Nevertheless, continued research on tsunami sediments, submarine landslides and volcanic 


\section{IMPORTANCE OF GEOLOGY IN TSUMANI SCIENCE}

eruptions promises to better define the global tsunami hazard from all generation mechanisms. Geology and geologists will continue to make essential contributions to this better understanding.

Many thanks to both Jon Hill and the indefatigable Simon Wallis for in-depth and constructive reviews that made a major contribution to the final text, and to Ellie Scourse for management of the review process. This paper is published with the permission of the CEO of the British Geological Survey, Natural Environmental Research Council, United Kingdom.

\section{References}

Abadie, S.M., HarRis, J.C., Grilli, S.T. \& FAbre, R. 2012. Numerical modeling of tsunami waves generated by the flank collapse of the Cumbre Vieja Volcano (La Palma, Canary Islands): tsunami source and near field effects. Journal of Geophysical Research, 117(C5), C0503.

Adams, J. 1990. Paleoseismicity of the Cascadia subduction zone: evidence from turbidites off the OregonWashington margin. Tectonics, 9, 569-583.

AltinoK, Y., Tinti, S., Alpar, B., Yalçiner, A.C., Ersoy, Ş., Bortolucci, E. \& Armigliato, A. 2001. The Tsunami of August 17, 1999 in Izmit Bay, Turkey. Natural Hazards, 24, 133-146.

AMBRASEYS, N.N. \& JACKSON, J.A. 1990. Seismicity and associated strain of central Greece between 1890 and 1988. Geophysical Journal International, 101, 663-708.

Assier-Rzadkiewicz, S., Heinrich, P., Sabatier, P.C., Savoye, B. \& Bourillet, J.-F. 2000. Numerical modelling of a landslide-generated tsunami: the 1979 Nice event. Pure and Applied Geophysics, 157, 1707-1727.

Atwater, B.A. 1987. Evidence for great Holocene earthquakes along the outer coast of Washington State. Science, 236, 942-944.

Atwater, B.F. \& Hemphill-Haley, E. 1997. Recurrence intervals for great earthquakes of the past 3,500 years at northeastern Willapa Bay, Washington. USGS Professional Paper 1576.

Bahlburg, H. \& Spiske, M. 2012. Sedimentology of tsunami inflow and backflow deposits: key differences revealed in a modern example. Sedimentology, 59, $1063-1086$.

BAILEY, E.B. \& WeIR, J. 1933. XIV. Submarine Faulting in Kimmeridgian Times: East Sutherland. Earth and Environmental Science Transactions of the Royal Society of Edinburgh, 57, 429-467.

Bardet, J.-P., Synolakis, C.E., Davies, H.L., Imamura, F. \& OKaL, E.A. 2003. Landslide tsunamis: recent findings and research directions. Pure and Applied Geophysics, 160, 1793-1809.

BIRNIE, J. 1981. Environmental changes in Shetland since the end of the last glaciation. Unpublished $\mathrm{PhD}$ thesis. University of Aberdeen.

Bondevik, S., Svendsen, J.I., Johnsen, G., Mangerud, J.A.N. \& Kaland, P.E. 1997a. The Storegga tsunami along the Norwegian coast, its age and run up. Boreas, 26, 29-53.

BondeviK, S., Svendsen, J.I. \& Mangerud, J.A.N. 1997b. Tsunami sedimentary facies deposited by the Storegga tsunami in shallow marine basins and coastal lakes, western Norway. Sedimentology, 44, $1115-1131$.

Bondevik, S., Mangerud, J., Dawson, S., Dawson, A. \& LoHNE, Ø. 2003. Record-breaking height for 8000year-old tsunami in the North Atlantic. EOS, Transactions of American Geophysical Union, 84, 289-293.

Bondevik, S., Løvholt, F., Harbitz, C., Mangerud, J., Dawson, A. \& Svendsen, J.I. 2005a. The Storegga Slide tsunami - comparing field observations with numerical simulations. Marine and Petroleum Geology, 22, 195-208.

Bondevik, S., Mangerud, J., Dawson, S., Dawson, A.R. \& LoHNE, Ø. $2005 b$. Evidence for three North Sea tsunamis at the Shetland Islands between 8000 and 1500 years ago. Quaternary Science Reviews, 24, 1757-1775.

Borrero, J.C. 2005. Field data and satellite imagery of tsunami effects in Banda Aceh. Science, 308, 1596.

Borrero, J.C., Dolan, J.F. \& Synolakis, C.E. 2001. Tsunamis within the Eastern Santa Barbara Channel. Geophysical Research Letters, 28, 643-646.

Borrero, J., LegG, M.R. \& Synokalis, C.E. 2004. Tsunami sources in the southern California Bight. Geophysical Research Letters, 31, https://doi.org/10. 1029/2004GL020078

BouRGEOIS, J. 2009. Geologic effects and records of tsunamis. In: Berbard, E.N. \& Robinson, A.R. (eds) The Sea, Tsunamis. 15, Harvard University Press: Cambridge, Massachusetts, 53-91.

Brothers, D.S., Luttrell, K.M. \& Chaytor, J.D. 2013. Sea-level-induced seismicity and submarine landslide occurrence. Geology, 41, 979-982.

Bryn, P., Berg, K., Forsberg, C.F., Solheim, A. \& Lien, R. 2005. Explaining the Storegga Slide. Marine and Petroleum Geology, 22, 11-19.

BugGe, T. 1983. Submarine slides on the Norwegian continental margin, with special emphasis on the Storegga area. IKU Report, 110, 1-152.

Bugge, T., Belderson, R.H. \& Kenyon, N.H. 1988. The Storegga Slide. Philosophical Transactions of the Royal Society of London. Series A, Mathematical and Physical Sciences, 325, 357-388.

Bungum, H., Lindholm, C. \& Faleide, J.I. 2005. Postglacial seismicity offshore mid-Norway with emphasis on spatio-temporal-magnitudal variations. Marine and Petroleum Geology, 22, 137-148.

Cadet, J.P., Kobauashi, K. et aL. 1987. The Japan Trench and its juncture with the Kuril trench: cruise results of the Kaiko project, Leg 3. Earth and Planetary Science Letters, 83, 267-285.

Canals, M., Lastras, G. et al. 2004. Slope failure dynamics and impacts from seafloor and shallow subseafloor geophysical data: case studies from the COSTA project. Marine Geology, 213, 9-72.

Chagué-Goff, C., Schneider, J.-L., Goff, J.R., Dominey-Howes, D. \& Strotz, L. 2011. Expanding the proxy toolkit to help identify past events - Lessons from the 2004 Indian Ocean Tsunami and the 2009 South Pacific Tsunami. Earth-Science Reviews, 107, 107-122.

Chagué-Goff, C., Andrew, A., Szczuciński, W., GoFf, J. \& Nishimura, Y. 2012. Geochemical signatures up 


\section{R. TAPPIN}

to the maximum inundation of the 2011 Tohoku-oki tsunami - Implications for the 869 AD Jogan and other palaeotsunamis. Sedimentary Geology, 282, $65-77$.

Chaytor, J.D., TEN BRINK, U.S., Solow, A.R. \& ANDREws, B.D. 2009. Size distribution of submarine landslides along the U.S. Atlantic margin. Marine Geology, 264, 16-27.

Cheng, W. \& Weiss, R. 2013. On sediment extent and runup of tsunami waves. Earth and Planetary Science Letters, 362, 305-309.

Cita, M.B., Beghi, C. ET AL. 1984. Turbidites and megaturbidites from the Herodotus abyssal plain (eastern Mediterranean) unrelated to seismic events. Marine Geology, 55, 79-101.

Clarke, S., Hubble, T. \& Airey, D. 2014. Morphology of Australia's Eastern continental slope and related tsunami hazard. In: Krastel, S. \& BehrmanN, J.-H. ET AL. (eds) Submarine Mass Movements and Their Consequences. Springer, 529-538.

Coleman, P.J. 1968. Tsunamis as geological agents. Journal of Geological Society of Australia, 15, 267-273.

Coleman, P.J. 1978. Tsunami sedimentation. In: FaIRBRIDGE, R.W. \& BourgeoIs, J. (eds) Encyclopedia of Sedimentology. Dowden, Hutchinson and Ross, Stroudsbourg, PA, 828-832.

Costa, P.J.M., Gelfenbaum, G. et AL. 2017. The application of microtextural and heavy mineral analysis to discriminate between storm and tsunami ep its. In: Scourse, E.M., Chapman, N.A., Tapp D.R. \& WALLIs, S.R. (eds) Tsunamis: Geology, Hazards and Risks. Geological Society, London, Special Publications, 456. First published online February 23, 2017, doi: $10.1144 /$ SP456.7

Dan, G., Sultan, N. \& Savoye, B. 2007. The 1979 Nice harbour catastrophe revisited: trigger mechanism inferred from geotechnical measurements and numerical modelling. Marine Geology, 245, 40-64.

Dawson, A.G. 1994. Geomorphological effects of tsunami run-up and backwash. Geomorphology, 10, 83-94.

Dawson, A.G. \& Stewart, I. 2007. Tsunami deposits in the geological record. Sedimentary Geology, 200, $166-183$.

Dawson, A.G., Long, D. \& Smith, D.E. 1988. The Storegga Slides: evidence from eastern Scotland for a possible tsunami. Marine Geology, 82, 271-276.

Dawson, A.G., Hindson, R., Andrade, C., Freitas, C., PARISH, R. \& BATEMAN, M. 1995. Tsunami sedimentation associated with the Lisbon earthquake of 1 November AD 1755: Boca do Rio, Algarve, Portugal. The Holocene, 5, 209-215.

Dominey-Howes, D.T.M., Humphreys, G.S. \& Hesse, P.P. 2006. Tsunami and palaeotsunami depositional signatures and their potential value in understanding the late-Holocene tsunami record. The Holocene, 16, 1095.

EINSELE, G. (ed) 1996. Marine sedimentary events and their records. Sedimentary Geology, 104, 1-257

ENET, F. \& GRILLI, S.T. 2005. Tsunami landslide generation: Modelling and experiments. Proceedings of the 5th International Conference on OceanWave Measurement and Analysis (WAVES 2005), Madrid, Spain, July 2005, ASCE Publication, paper 88.
Enet, F. \& GRILLI, S.T. 2007. Experimental study of tsunami generation by three-dimensional rigid underwater landslides. Journal of Waterway, Port, Coastal, and Ocean Engineering, 133, 442-454.

Enet, F., Grilli, S.T. \& Watts, P. 2003. Laboratory experiments for tsunamis generated by underwater landslides: comparison with numerical modeling. Proceedings of the 13th International Offshore and Polar Engineering Conference, ISOPE03, Honolulu, Hawaii, 3, 372-379.

FALVARD, S. \& PARIS, R. 2017. X-ray tomography of tsunami deposits: towards a new depositional model of tsunami deposits. Sedimentology, 64, 453-477.

Feldens, P., Schwarzer, K., Sakuna, D., Szczuciński, W. \& SompongchaiYakul, P. 2012. Sediment distribution on the inner continental shelf off Khao Lak (Thailand) after the 2004 Indian Ocean tsunami. Earth Planets Space, 64, 875-887.

Felton, E.A. 2002. Sedimentology of rocky shorelines: 1. A review of the problem, with analytical methods, and insights gained from the Hulopoe Gravel and the modern rocky shoreline of Lanai, Hawaii. Sedimentary Geology, 152, 221-245.

Felton, E.A., Crook, K.A.W. \& Keating, B.H. 2000 The Hulopoe gravel, Lanai, Hawaii: new sedimentological data and their bearing on the 'giant wave' (mega-tsunami) emplacement hypothesis. Pure and Applied Geophysics, 157, 1257-1284.

Fine, I.V., Rabinovich, A.B., Bornhold, B.D., Thomson, R.E. \& Kulikov, E.A. 2005. The Grand Banks landslide-generated tsunami of November 18, 1929: preliminary analysis and numerical modeling. Marine Geology, 215, 45-57.

ForSBERG, C.F. 2002. Reconstruction of the Pre-Storegga Slide Stratigaphy. Norsk Hydro Report 37-00NHX15-00040.

FrancIS, P.W. 1985. The origin of the 1883 Krakatau tsunamis. Journal of Volcanology and Geothermal Research, 25, 349-363.

Fritz, H.M., KongKo, W. ET AL. 2007. Extreme runup from the 17 July 2006 Java tsunami. Geophysical Research Letters, 34, https://doi.org/10.1029/2007 GL029404

Fryer, G.J., Watts, P. \& Pratson, L.F. 2004. Source of the great tsunami of 1 April 1946: a landslide in the upper Aleutian forearc. Marine Geology, 203, 201-218.

FujiI, Y., Satake, K., Sakai, S.I., Shinohara, M. \& KANAZAWA, T. 2011. Tsunami source of the 2011 off the Pacific coast of Tohoku Earthquake. Earth Planets Space, 63, 815-820.

GEIST, E.L. 1998. Local tsunamis and earthquake source parameters. Advances in Geophysics, 39, 117-209.

GeIst, E.L. 2000. Origin of the 17 July, 1998 Papua New Guinea tsunami: Earthquake or landslide? Seismological Research Letters, 71, 344-351.

Geist, E.L. \& Parsons, T. 2009. Assessment of source probabilities for potential tsunamis affecting the U.S. Atlantic coast. Marine Geology, 264, 98-108.

Geist, E.L., Lynett, P.J. \& Chaytor, J.D. 2009. Hydrodynamic modeling of tsunamis from the Currituck landslide. Marine Geology, 264, 41-52.

Gelfenbaum, G. \& JafFe, B. 2003. Erosion and sedimentation from the 17 July, 1998 Papua New Guinea tsunami. Pure and Applied Geophysics, 160, 1969-1999. 


\section{IMPORTANCE OF GEOLOGY IN TSUMANI SCIENCE}

Gisler, G., Weaver, R. \& Gittings, M. 2006. SAGE calculations of the tsunami threat from La Palma. Science of Tsunami Hazards, 24, 288-301.

Goff, J., Chagué-Goff, C. \& Nichol, S. 2001. Paleotsunami deposits: a New Zealand perspective. Sedimentary Geology, 143, 1-6.

Goff, J., McFadgen, B.G. \& Chagué-Goff, C. 2004. Sedimentary differences between the 2002 Easter storm and the 15th Century Okoropunga tsunami, southeastern North Island, New Zealand. Marine Geology, 204, 235-250.

GoldFinger, C., Nelson, C.H. ET AL. 2012. Turbidite event history - Methods and implications for Holocene paleoseismicity of the Cascadia subduction zone. U.S. Geological Survey Professional Paper 1661-F, 170.

Goto, K., Chavanich, S.A. et aL. 2007. Distribution, origin and transport process of boulders deposited by the 2004 Indian Ocean tsunami at Pakarang Cape, Thailand. Sedimentary Geology, 202, 821-837.

Goto, K., Imamura, F. et AL. 2008a. Distribution and Significance of the 2004 Indian Ocean Tsunami Deposits: Initial Results from Thailand and Sri Lanka, Tsunamiites. Elsevier, Amsterdam.

Goto, K., TADA, R. ET AL. 2008b. Lateral lithological and compositional variations of the Cretaceous/Tertiary deep-sea tsunami deposits in northwestern Cuba. Cretaceous Research, 29, 217-236.

Goto, K., Kawana, T. \& Imamura, F. 2010a. Historical and geological evidence of boulders deposited by tsunamis, southern Ryukyu Islands, Japan. Earth-Science Reviews, 102, 77-99.

Goto, K., Miyagi, K., Kawamata, H. \& Imamura, F. $2010 b$. Discrimination of boulders deposited by tsunamis and storm waves at Ishigaki Island, Japan. Marine Geology, 269, 34-45.

Goto, K., Chagué-Goff, C. et aL. 2011. New insights of tsunami hazard from the 2011 Tohoku-oki event. Marine Geology, 290, 46-50.

Grauert, M., BJörck, S. \& BondeviK, S. 2001. Storegga tsunami deposits in a coastal lake on Suouroy, the Faroe Islands. Boreas, 30, 263-271.

GrigG, R.W. \& Jones, A.T. 1997. Uplift caused by lithospheric flexure in the Hawaiian Archipelago as revealed by elevated coral deposits. Marine Geology, 141, 11-25.

GrigGS, G.B. \& KULM, L.D. 1970. Sedimentation in Cascadia deep-sea Channel. Geological Society of America Bulletin, 81, 1361-1384.

GriLli, S.T. \& WatTs, P. 1999. Modelling of waves generated by a moving submerged body: applications to underwater landslides. Engineering Analysis with Boundary Elements, 23, 645-656.

Grilli, S.T. \& WatTs, P. 2001. Modeling of tsunami generation by an underwater landslide in a 3D-NWT. Proceedings of the 11th Offshore and Polar Engineering Conference (ISOPE01), Stavanger, Norway, June 2001, III, 132-139.

GriLli, S.T. \& WATTS, P. 2005. Tsunami generation by submarine mass failure part I: modeling, experimental validation, and sensitivity analyses. Journal of Waterway, Port, Coastal, and Ocean Engineering, 131, 283-297.

Grilli, S.T., Vogelmann, S. \& Watts, P. 2002. Development of a 3D numerical wave tank for modelling tsunami generation by underwater landslides. Engineering Analysis with Boundary Elements, 26, 301-313.

Grilli, S.T., TaYlor, O.-D.S., BAXTer, C.D.P. \& MARETZKI, S. 2009. A probabilistic approach for determining submarine landslide tsunami hazard along the upper east coast of the United States. Marine Geology, 264, 74-97.

Grilli, S.T., Harris, J.C., Tajalli Bakhsh, T.S., Masterlark, T.L., Kyriakopoulos, C., Kirby, J.T. \& SHI, F. 2013. Numerical simulation of the 2011 Tohoku Tsunami based on a new transient FEM co-seismic source: comparison to far- and near-field observations. Pure and Applied Geophysics, 170, 1333-1359.

Grilli, S., O'Reilly, C. ET AL. 2015. Modeling of SMF tsunami hazard along the upper US East Coast: detailed impact around Ocean City, MD. Natural Hazards, 76, $705-746$.

Gusman, A.R., Tanioka, Y., Sakai, S. \& Tsushima, H. 2012. Source model of the great 2011 Tohoku earthquake estimated from tsunami waveforms and crustal deformation data. Earth and Planetary Science Letters, 341-344, 234-242.

GutenBerg, B. 1939. Tsunamis and earthquakes. Bulletin of the Seismological Society of America, 29, 517-526.

Haflidason, H., Lien, R., SeJrup, H.P., Forsberg, C.F. \& BRYN, P. 2005. The dating and morphometry of the Storegga Slide. Marine and Petroleum Geology, $123-136$.

Hall, A.M., Hansom, J.D., Williams, D.M. \& Jarvis, J. 2006. Distribution, geomorphology and lithofacies of cliff-top storm deposits: examples from the highenergy coasts of Scotland and Ireland. Marine Geology, 232, 131-155.

HAMMACK, J.L. 1973. A note on tsunamis: their generation and propagation in an ocean of uniform depth. Journal of Fluid Mechanics, 60, 769-799.

HAMPTON, M. 1972. The role of subaqueous debris flow in generating turbidity currents. Journal of Sedimentary Research, 42, 775-993.

Hampton, M.A., Lee, H.J. \& Locat, J. 1996. Submarine landslides. Reviews of Geophysics, 34, 33-59.

HARBITZ, C.B. 1992. Model simulation of tsunamis generated by the Storegga Slides. Marine Geology, 105, $1-21$.

Hasegawa, H.S. \& Kanamori, H. 1987. Source mechanism of the magnitude 7.2 Grand Banks earthquake of November 1929: double couple or submarine landslide? Bulletin of the Seismological Society of America, 77, 1984-2004.

Haugen, K.B., Løvholt, F. \& Harbitz, C.B. 2005. Fundamental mechanisms for tsunami generation by submarine mass flows in idealised geometries. Marine and Petroleum Geology, 22, 209-217.

Hearty, J.P. 1997. Boulder deposits from large waves during the last interglaciation on North Eleuthera island, Bahamas. Quaternary Research, 48, 326-338.

Heezen, B.C. \& EwING, M. 1952. Turbidity currents and submarine slumps, and the 1929 Grand Banks Earthquake. American Journal of Science, 250, 849-873.

Heezen, B.C., Ericsson, D.B. \& Ewing, M. 1954. Further evidence of a turbidity current following the 1929 Grand Banks earthquake. Deep Sea Research, 1, 193-202. 


\section{R. TAPPIN}

Heidarzadeh, M., Pirooz, M.D., ZaKer, N.H., Yalciner, A.C., Mokhtari, M. \& Esmaeily, A. 2008. Historical tsunami in the Makran Subduction Zone off the southern coasts of Iran and Pakistan and results of numerical modeling. Ocean Engineering, 35, 774-786.

HeINRICH, P. 1992. Nonlinear water waves generated by submarine and aerial landslides. Journal of Waterways, Port, Coast, Ocean Engineering, 118, 249-266.

Heinrich, P., Piatanesi, A., Okal, E.A. \& Hébert, H. 2000. Near-field modelling of the July 17, 1998 event in Papua New Guinea. Geophysical Research Letters, 27, 3037-3040.

Hill, J., Collins, G.S., Avdis, A., Kramer, S.C. \& PigGOTT, M.D. 2014. How does multiscale modelling and inclusion of realistic palaeobathymetry affect numerical simulation of the Storegga Slide tsunami? Ocean Modelling, 83, 11-25.

Houtz, R.E. 1962. The 1953 Suva earthquake and tsunami. Bulletin of the Seismological Society of America, 52, $1-12$.

HÜHNerbach, V., Masson, D.G. \& COSTA PRoJect PARTNERs 2004. Landslides in the north Atlantic and its adjacent seas: an analysis of their morphology, setting and behaviour. Marine Geology, 213, 343-362.

Hunt, J.E., Wynn, R.B., Masson, D.G., Talling, P.J. \& Teagle, D.A.H. 2011. Sedimentological and geochemical evidence for multistage failure of volcanic island landslides: a case study from Icod landslide on north Tenerife, Canary Islands. Geochemistry, Geophysics, Geosystems, 12, Q12007.

Hunt, J.E., Wynn, R.B., Talling, P.J. \& Masson, D.G. 2013. Multistage collapse of eight western Canary Island landslides in the last $1.5 \mathrm{Ma}$ : sedimentological and geochemical evidence from subunits in submarine flow deposits. Geochemistry, Geophysics, Geosystems, 14, 2159-2181.

Huntington, K., Bourgeois, J., Gelfenbaum, G., Lynett, P., Jaffe, B., Yeh, H. \& Weiss, R. 2007. Sandy signs of a tsunami's onshore depth and speed. Eos, 88, 577-578.

Hurukawa, N., Tsuji, Y. \& Waluyo, B. 2003. The 1998 Papua New Guinea earthquake and its fault plane estimated from relocated aftershocks. Pure and Applied Geophysics, 160, 1829-1841.

IINUMA, T., HinO, R. ET AL. 2012. Coseismic slip distribution of the 2011 off the Pacific Coast of Tohoku Earthquake (M9.0) refined by means of seafloor geodetic data. Journal of Geophysical Research: Solid Earth, 117, B07409.

Ikehara, K., Irino, T., Usami, K., Jenkins, R., Omura, A. \& Ashi, J. 2014. Possible submarine tsunami deposits on the outer shelf of Sendai Bay, Japan resulting from the 2011 earthquake and tsunami off the Pacific coast of Tohoku. Marine Geology, 358 $120-127$.

Ishimura, D. \& MiYauchi, T. 2015. Historical and paleotsunami deposits during the last 4000 years and their correlations with historical tsunami events in Koyadori on the Sanriku Coast, northeastern Japan. Progress in Earth and Planetary Science, 2, 16.

Jaffe, B.E. \& Gelfenbaum, G. 2002. Using tsunami deposits to improve assessment of tsunami risk. Solutions to Coastal Disasters '02, Conference
Proceedings, ASCE, February 24-27, 2002. American Society of Civil Engineers, San Diego, California, United States, 836-847.

JAFFe, B.E. \& Gelfenbuam, G. 2007. A simple model for calculating tsunami flow speed from tsunami deposits. Sedimentary Geology, 200, 347-361.

JAFFE, B., BUCKLEY, M. ET AL. 2011. Flow speed estimated by inverse modeling of sandy sediment deposited by the 29 September 2009 tsunami near Satitoa, east Upolu, Samoa. Earth-Science Reviews, 107, $23-37$.

Jankaew, K., Atwater, B.F., Sawai, Y., Choowong, M., Charoentitirat, T., Martin, M.E. \& PrenderGAST, A. 2008. Medieval forewarning of the 2004 Indian Ocean tsunami in Thailand. Nature, $\mathbf{4 5 5}$, $1228-1231$.

Jansen, E., Befring, S., Bugge, T., Eidvin, T., HolteDAHL, H. \& SEJRUP, H.P. 1987. Large submarine slides on the Norwegian continental margin: sediments, transport and timing. Marine Geology, 78, 77-107.

JiANG, L. \& LeBLOND, P.H. 1992. The coupling of a submarine slide and the surface wave which it generates. Journal of Geophysical Research, 97, 12731-12744.

JiANG, L. \& LEBLOND, P.H. 1994. Three dimensional modelling of tsunami generation due to submarine mudslide. Journal of Physical Oceanography, 24, 559-573.

KANAMORI, H. 1972. Mechanisms of tsunami earthquakes. Physics of the Earth and Planetary Interiors, 6, 346-359.

Kastens, K.A. \& Cita, M.B. 1981. Tsunami-induced sediment transport in the abyssal Mediterranean Sea. Geological Society of America Bulletin, 92, 591-604.

Kawamura, K., Sasaki, T., Kanamatsu, T., SaKaguchi, A. \& OgaWA, Y. 2012. Large submarine landslides in the Japan Trench: a new scenario for additional tsunami generation. Geophysical Research Letters, 39, L05308.

Kawata, Y., Benson, B.C. ET AL. 1999. Tsunami in Papua New Guinea was as intense as first thought. Eos, Transactions of the American Geophysical Union, 80, 101, $104-105$.

Keating, H.B. \& McGuiRe, J.W. 2000. Island edifice failures and associated tsunami hazards. Pure and Applied Geophysics, 157, 899-955.

Kench, P.S., McLean, R.F. ET AL. 2006. Geological effects of tsunami on mid-ocean atoll islands: the Maldives before and after the Sumatran tsunami. Geology, 34, 177-180.

Kikuchi, M., Yamanaka, Y., Abe, K. \& Morita, Y. 1999. Source rupture process of the Papua New Guinea earthquake of July 17th, 1998 inferred from teleseismic body waves. Earth Planets Space, 51, 1319-1324.

Kon'NO, E.E. 1961. Geological observations of the Sanriku coastal region damaged by tsunami due to the Chile earthquake in 1960, Contributions to the Institute of Geology and Paleontology, Tohoku University, $1-40$.

Kuenen, P.H. 1957. Sole markings of graded greywacke beds. Journal of Geology, 65, 231-258.

Kulikov, E.A., Rabinovich, A.B., Thomson, R.E. \& BorNHOLD, B.D. 1996. The landslide tsunami of November 3, 1994, Skagway Harbor, Alaska. Journal of Geophysical Research: Oceans, 101, 6609-6615. 


\section{IMPORTANCE OF GEOLOGY IN TSUMANI SCIENCE}

Kvalstad, T.J., Andresen, L., Forsberg, C.F., Berg, K., Bryn, P. \& Wangen, M. 2005. The Storegga Slide: evaluation of triggering sources and slide mechanics. Marine and Petroleum Geology, 22, 245-256.

LAberG, J.S. \& Vorren, T.O. 2000. The Trænadjupet Slide, offshore Norway - morphology, evacuation and triggering mechanisms. Marine Geology, 171, 95-114.

LeBlond, P.H. \& Jones, A. 1995. Underwater landslides ineffective at tsunami generation. Science of Tsunami Hazards, 13, 25-26.

LEE, H.J. 2009. Timing of occurrence of large submarine landslides on the Atlantic Ocean margin. Marine Geology, 264, 53-64.

Le Roux, J.P. \& VArgas, G. 2005. Structure and depositional processes of a gravelly tsunami deposit in a shallow marine setting: Lower Cretaceous Miyako Group, Japan - discussion. Sedimentary Geology, 201, $485-487$.

Liu, P.L.-F., Wu, T.-R., Raichlen, F., Synolakis, C.E. \& Borrero, J.C. 2005. Runup and rundown generated by three-dimensional sliding masses. Journal of Fluid Mechanics, 536, 107-144.

Locat, J., Locat, P., LeE, H.J. \& IMRAN, J. 2004. Numerical analysis of the mobility of the Palos Verdes debris avalanche, California, and its implication for the generation of tsunamis. Marine Geology, 20, 269-280.

Locat, J., Lee, H., ten Brink, U.S., Twichell, D., Geist, E. \& Sansoucy, M. 2009. Geomorphology, stability and mobility of the Currituck slide. Marine Geology, 264, 28-40.

Long, D., Smith, D.E. \& Dawson, A.G. 1989. A Holocene tsunami deposit in eastern Scotland. Journal of Quaternary Science, 4, 61-66.

LóPEZ, A.M. \& OKAL, E.A. 2006. A seismological reassessment of the source of the 1946 Aleutian 'tsunami' earthquake. Geophysics Journal International, 165, 835-849.

Løvholt, F., Harbitz, C.B. \& Haugen, K.B. 2005. A parametric study of tsunamis generated by submarine slides in the Ormen Lange/Storegga area off western Norway. Marine and Petroleum, Geology, 22, 219-231.

Løvholt, F., Pedersen, G. \& Gisler, G. 2008. Oceanic propagation of a potential tsunami from the La Palma Island. Journal of Geophysical Research, 113 , https://doi.org/10.1029/2007JC004603

Løvholt, F., Kaiser, G., Glimsdal, S., Scheele, L., Harbitz, C.B. \& Pedersen, G. 2012. Modeling propagation and inundation of the 11 March 2011 Tohoku tsunami. Natural Hazards and Earth Systems Science, 12, 1017-1028.

Løvholt, F., Pedersen, G., Harbitz, C.B., Glimsdal, S. \& KIM, J. 2015. On the characteristics of landslide tsunamis. Philosophical Transactions of the Royal Society A: Mathematical, Physical and Engineering Science, 373, https://doi.org/10.1098/rsta.2014.0376

Ludwig, K.R., Szabo, B.J., Moore, J.G. \& Simmons, K.R. 1991. Crustal subsidence rate of Hawaii determined from $234 \mathrm{U} / 238 \mathrm{U}$ ages of drowned coral reefs. Geology, 19, 171-174.

LynetT, P. \& LiU, P.L. 2002. A numerical study of submarine landslide generated waves and runup. Proceedings of the Royal Society of London, A, 458, 2885-2910.
MA, G., Kirby, J.T. \& SHI, F. 2013. Numerical simulation of tsunami waves generated by deformable submarine landslides. Ocean Modelling, 69, 146-165.

Ma, G., Kirby, J.T., Hsu, T.-J. \& Shi, F. 2015. A twolayer granular landslide model for tsunami wave generation: theory and computation. Ocean Modelling, 93, $40-55$.

Macinnes, B.T., Weiss, R., Bourgeois, J. \& Pinegina, T.K. 2010. Slip distribution of the 1952 Kamchatka Great Earthquake based on near-field tsunami deposits and historical records. Bulletin of the Seismological Society of America, 100, 1695-1709.

Macinnes, B.T., Gusman, A.R., LeVeque, R.J. \& TANIOKA, Y. 2013. Comparison of earthquake source models for the 2011 Tohoku event using tsunami simulations and near-field observations. Bulletin of the Seismological Society of America, 103, 1256-1274.

Maeda, T., Furumura, T., Sakai, S.I. \& Shinohara, M. 2011. Significant tsunami observed at ocean-bottom pressure gauges during the 2011 off the Pacific coast of Tohoku Earthquake. Earth, Planets and Space, 63, 803-808.

Maeno, F. \& Imamura, F. 2011. Tsunami generation by a rapid entrance of pyroclastic flow into the sea during the 1883 Krakatau eruption, Indonesia. Journal of Geophysical Research, 116, B09205.

Marinatos, S. 1939. The volcanic destruction of Minoan Crete. Antiquity, 13, 425-439.

Martin, M.E., Weiss, R., Bourgeois, J., Pinegina, T.K., Houston, H. \& Titov, V.V. 2008. Combining constraints from tsunami modeling and sedimentology to untangle the 1969 Ozernoi and 1971 Kamchatskii tsunamis. Geophysical Research Letters, 35, L01610.

Maslin, M., Owen, M., DaY, S. \& LONG, D. 2004. Linking continental-slope failures and climate change: testing the clathrate gun hypothesis. Geology, 32, 53-56.

Masson, D.G., Harbitz, C.B., Wynn, R.B., Pedersen, G. \& Løvholt, F. 2006. Submarine landslides: processes, triggers and hazard prediction. Philosophical Transactions of the Royal Society, A, 364, 2009-2039.

Masson, D.G., Wynn, R.B. \& Talling, P.J. 2009. Large landslides on passive continental margins: processes, hypotheses and outstanding questions. In: MOSHER, D.C., Shipp, R.C., Moscardilli, L., Chaytor, J.D., BaXter, C.D.P., Lee, H.J. \& Urgeles, R. (eds) Submarine Mass Movements and Their Consequences. Springer Science, Dordrecht, Heidelberg, London, New York, 153-165.

MastronuzZI, G. \& SANso, P. 2004. Large boulder accumulations by extreme waves along the Adriatic coast of southern Apulia (Italy). Quaternary International, 120, $1173-1184$.

McCue, K.F. 1998. An AGSO perspective of PNG's tsunamagenic earthquake of 17 July 1998. AusGeo International, 9, 1-2.

McMurtry, G.M., Herrero-Bervera, E., Cremer, M., Resig, J., Sherman, C., Smith, J.R. \& Torresan, M.E. 1999. Stratigraphic constraints on the timing and emplacement of the Alika 2 giant Hawaiian submarine landslide. Journal of Volcanology and Geothermal Research, 94, 35-58.

McMurtry, G.M., Fryer, G.J. et AL. 2004a. Megatsunami deposits on Kohala volcano, Hawaii, from flank collapse of Mauna Loa. Geology, 32, 741-744. 


\section{R. TAPPIN}

McMurtry, G.M., Watts, P., Fryer, G.J., Smith, J.R. \& IMAMURA, F. 2004b. Giant landslides, mega-tsunamis, and paleo-sea level in the Hawaiian Islands. Marine Geology, 203, 219-233.

Milne, J. 1898. Earthquakes and Other Earth Movements. Paul, Trench, Trübner \& Co., London, UK.

Minoura, K. \& NAKAYA, S. 1991. Traces of tsunami preserved in inter-tidal lacustrine and marsh deposits: some examples from Northeast Japan. Journal of Geology, 99, 265-287.

Minoura, K., Imamura, F., Takahashi, T. \& Shuto, N. 1997. Sequence of sedimentation processes caused by the 1992 Flores tsunami: evidence from Babi Island. Geology, 25, 523-526.

Minoura, K., Imamura, F., Sugawara, D., Kono, Y. \& IwASHITA, T. 2001. The 869 Jogan tsunami deposit and recurrence interval of large-scale tsunami on the Pacific coast of northeast Japan. Journal of Natural Disaster Science, 23, 83-88.

Montessus de Ballore, F. 1907. La Science Séismologique. A. Colin, Paris, France.

Moore, A.L., McAdoo, B.G. \& Ruffman, A. 2007. Landward fining from multiple sources in a sand sheet deposited by the 1929 Grand Banks tsunami, Newfoundland. Sedimentary Geology, 200, 336-346.

Moore, G.W. \& Moore, J.G. 1988. Large-scale bedforms in boulder gravel produced by giant waves in Hawaii: sedimentologic consequences of convulsive geologic events. Special Papers of the Geological Society of America, 101-110.

Moore, J.G. 1964. Giant submarine landslides on the Hawaiian Ridge. United States Geological Survey Professional Paper 501-D, 95-98.

Moore, J.G. \& Moore, G.W. 1984. Deposit from a giant wave on the island of Lanai, Hawaii. Science, 226, $1312-1315$

Moore, J.G., Clague, D.A., Holcomb, R.T., Lipman, P.W., Normark, W.R. \& Torresan, M.E. 1989. Prodigious submarine landslides on the Hawaiian Ridge. Journal of Geophysical Research, 94, 17465-17484.

Moore, J.G., Bryan, W.B., BeEson, M.H. \& Normark, W.R. 1995. Giant blocks in the South Kona landslide, Hawaii. Geology, 23, 125-128.

Mori, N., Takahashi, T., Yasuda, T. \& Yanagisawa, H. 2011. Survey of 2011 Tohoku earthquake tsunami inundation and run-up. Geophysical Research Letters, 38, L00G14.

Morton, R.A., Richmond, B.M., JafFe, B.E. \& GelfenBAUM, G. 2006. Reconnaissance Investigation of Caribbean Extreme Wave Deposits - Preliminary Observations, Interpretations, and Research Directions. Open-File Report 2006-1293, US Department of the Interior, US Geological Survey.

Morton, R.A., Gelfenbaum, G. \& Jaffe, B.E. 2007. Physical criteria for distinguishing sandy tsunami and storm deposits using modern examples. Sedimentary Geology, 200, 184-207.

Morton, R.A., Goff, J.R. \& Nichol, S.L. 2008. Hydrodynamic implications of textural trends in sand deposits of the 2004 tsunami in Sri Lanka. Sedimentary Geology, 207, 56-64.

MurTy, T.S. 1979. Submarine slide-generated water waves in Kitimat Inlet, British Columbia. Journal of Geophysical Research, 84, 7777-7779.
Myles, D. 1985. The Great Waves. Robert Hale Ltd., London.

MyLROIE, J.E. 2008. Late Quaternary sea-level position: evidence from Bahamian carbonate deposition and dissolution cycles. Quaternary International, 183, 61-75.

Nanayama, F., Shigeno, K., Satake, K., Shimokawa, K., Koitabashi, S., Mayasaka, S. \& Ishi, M. 2000. Sedimentary differences between 1993 HokkaidoNansei-Oki tsunami and 1959 Miyakijima typhoon at Tasai, southwestern Hokkaido, northern Japan. Sedimentary Geology, 135, 255-264.

Newman, A.V. \& OKal, E.A. 1998a. Moderately slow character of the July 17, 1998 Sandaun earthquake as studied by teleseismic energy estimates (abs.). Eos Transactions, American Geophysical Union, 79, Fall Meeting, Supplement F564.

Newman, A.V. \& OKal, E.A. 1998b. Teleseismic estimates of radiated seismic energy: the E/M0 discriminant for tsunami earthquakes. Journal of Geophysical Research, 103, 26885-26826, 26898.

Noda, A., Katayama, H. ET AL. 2007. Evaluation of tsunami impacts on shallow marine sediments: an example from the tsunami caused by the 2003 Tokachi-oki earthquake, northern Japan. Sedimentary Geology, 200, 314-327.

Noormets, R., Felton, E.A. \& Crook, K.A.W. 2002. Sedimentology of rocky shorelines: 2 . Shoreline megaclasts on the north shore of Oahu, Hawaii: origins and history. Sedimentary Geology, 150, 31-45.

Normark, W.R., McGann, M. \& Sliter, R. 2004. Age of Palos Verdes submarine debris avalanche, southern California. Marine Geology, 203, 247-259.

NotT, J. 1997. Extremely high-energy wave deposits inside the Great Barrier Reef, Australia, determining the cause: tsunami or tropical cyclone. Marine Geology, 141, 193-207.

NotT, J. 2003. Tsunami or stormwaves? Determining the origin of a spectacular field of wave emplaced boulders using numerical storm, surge and wave models and hydrodynamic transport equations. Journal of Coastal Research, 19, 348-356.

Novikova, T., Papadopoulos, G.A. \& McCoy, F.W. 2011. Modelling of tsunami generated by the giant Late Bronze Age eruption of Thera, South Aegean Sea, Greece. Geophysical Journal International, 186, $665-680$.

O’Grady, D.B., Syvitski, J.P.M., Pratson, L.F. \& Sarg, J.F. 2000. Categorizing the morphologic variability of siliciclastic passive continental margins. Geology, 28, 207-210.

OKADA, Y. 1985. Surface deformation due to shear and tensile faults in a half-space. Bulletin of the Seismological Society of America, 75, 1135-1154.

OKAL, E. \& HerberT, H. 2007. Far-field simulation of the 1946 Aleutian tsunami. Geophysical Journal International, 169, 129-1238.

Pareschi, M.T., Favalli, M. \& Boschi, E. 2006. Impact of the Minoan tsunami of Santorini: simulated scenarios in the eastern Mediterranean. Geophysical Research Letters, 33, https://doi.org/10.1029/ 2006GL027205

Paris, R., Pérez Torrado, F.J., Cabrera, M.D.C., Wassmer, P., Schneider, J.L. \& Carracedo, J.C. 


\section{IMPORTANCE OF GEOLOGY IN TSUMANI SCIENCE}

2004. Tsunami-induced conglomerates and debrisflow deposits on the Western Coast of Gran Canaria (Canary Islands). Acta Vulcanalogica, 16, 133-136.

Paris, R., Lavigne, F., Wassmer, P. \& Sartohadi, J. 2007. Coastal sedimentation associated with the December 26, 2004 tsunami in Lhok Nga, west Banda Aceh (Sumatra, Indonesia). Marine Geology, 238, 93-106.

Paris, R., Wassmer, P. ET AL. 2014. Coupling eruption and tsunami records: the Krakatau 1883 case study, Indonesia. Bulletin of Volcanology, 76, 1-23.

Pelinovsky, E. 2004. Tsunami gnerated by the volcano eruption on July 12-13, 2003 T Montserrat, Lesser Antilles. Science of Tsunami Hazards, 22, 44-45.

Peters, R., Jaffe, B. \& Gelfenbaum, G. 2007. Distribution and sedimentary characteristics of tsunami deposits along the Cascadia margin of western North America. Sedimentary Geology, 200, 372-386.

PICKERING, K.T. 1984. The Upper Jurassic 'Boulder Beds' and related deposits: a fault-controlled submarine slope, NE Scotland. Journal of the Geological Society of London, 141, 357-374.

PIPER, D.J.W. \& ASKU, A.E. 1987. The source and origin of the 1929 Grand Banks turbidity current inferred from sediment budgets. Geo Marine Letters, 7, $177-182$.

Piper, D.J.W., Shor, A.N. \& Clarke, J.E.H. 1988. The 1929 Grand Banks earthquake, slump and turbidity current. Geological Society of America Special Paper, 229, 77-92.

Polonia, A., Bonatti, E., Camerlenghi, A., Lucch, R.G., PANieri, G. \& Gasperini, L. 2013. Mediterranean megaturbidite triggered by the AD 365 Crete earthquake and tsunami. Scientific Reports, 3, 1-12.

Quidelleur, X., Hildenbrand, A. \& Samper, A. 2008. Causal link between Quaternary paleoclimatic changes and volcanic islands evolution. Geophysical Research Letters, 35, L02303.

Rabinovich, A.B., Thomson, R.E., Kulikov, E.A., Bornhold, B.D. \& FInE, I.V. 1999. The landslidegenerated tsunami of November 3, 1994 in Skagway Harbor, Alaska: a case study. Geophysical Research Letters, 26, 3009-3012.

Ramalho, R.S., Winckler, G. et al. 2015. Hazard potential of volcanic flank collapses raised by new megatsunami evidence. Science Advances, 1, https:// doi.org/10.1126/sciadv.1500456

ReImNitZ, E. \& MARShall, N.F. 1965. Effects of the Alaska earthquake and tsunami on recent deltaic sediments. Journal of Geophysical Research, 70, $2363-2376$.

Romano, F., Piatanesi, A. et aL. 2012. Clues from joint inversion of tsunami and geodetic data of the 2011 Tohoku-oki earthquake. Scientific Reports, 2, https:// doi.org/10.1038/srep00385

Rubin, K.H., Fletcher, C.H., III \& Sherman, C. 2000. Fossiliferous Lanai deposits formed by multiple

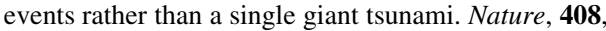
675-681.

Sakuna, D., Szczuciński, W., Feldens, P., Schwarzer, K. \& KhOKiattiwong, S. 2012. Sedimentary deposits left by the 2004 Indian Ocean tsunami on the inner continental shelf offshore of Khao Lak, Andaman Sea (Thailand). Earth, Planets and Space, 64, 931-943.
Satake, K., Bourgeois, J. et al. 1993. Tsunami field survey of the 1992 Nicaragua earthquake. Eos, Transactions of the American Geophysical Union, 74, 145-157.

Satake, K., Shimazaki, K., Tsuji, Y. \& Ueda, K. 1996. Time and size of a giant earthquake in Cascadia inferred from Japanese tsunami records of January 1700. Nature, 379, 246-249.

Satake, K., FujiI, Y., Harada, T. \& Namegaya, Y. 2013. Time and space distribution of coseismic slip of the 2011 Tohoku earthquake as inferred from tsunami waveform data. Bulletin of the Seismological Society of America, 103, 1473-1492.

Sawai, Y., Jankaew, K., Martin, M.E., Prendergast, A., Choowong, M. \& Charoentitirat, T. 2009. Diatom assemblages in tsunami deposits associated with the 2004 Indian Ocean tsunami at Phra Thong Island, Thailand. Marine Micropaleontology, 73, $70-79$.

Sawai, Y., Namegaya, Y., Okamura, Y., Satake, K. \& SHISHIKURA, M. 2012. Challenges of anticipating the 2011 Tohoku earthquake and tsunami using coastal geology. Geophysical Research Letters, 39, L21309.

Self, S. \& Rampino, M.R. 1981. The 1883 eruption of Krakatau. Nature, 294, 699-704.

Shanmugam, G. 2006. The tsunamite problem. Journal of Sedimentary Research, 76, 718-730.

Shanmugam, G. 2012. Process-sedimentological challenges in distinguishing paleo-tsunami deposits. Natural Hazards, 1-26.

Shepard, F.P., MacDonald, G.A. \& Cox, D.C. 1950. The tsunami of April 1st 1946 (Hawaii). California University, Scripps Institute Oceanography Bulletin, 5, 391-528.

Shi, S., Dawson, A.G. \& Smith, D.E. 1995. Coastal sedimentation associated with the December 12th, 1992 Tsunami in Flores, Indonesia. PAGEOPH, 144, $525-536$.

Shiki, T., Cita, M.B. \& Gorsline, D.S. 2000. Sedimentary features of seismites, seismo-turbidites and tsunamiites - an introduction. Sedimentary Geology, 135, vii-ix.

Shiki, T., Tsuji, Y., Yamazaki, T. \& Minoura, K. 2008. Tsunamiites. Elsevier, Amsterdam.

Smith, D.E., ShI, S. ET AL. 2004. The Holocene Storegga Slide tsunami in the United Kingdom. Quaternary Science Reviews, 23, 2291-2321.

Smith, D.E., Foster, I.D.L., Long, D. \& ShI, S. 2007. Reconstructing the pattern and depth of flow onshore in a palaeotsunami from associated deposits. Sedimentary Geology, 200, 362-371.

Smith, D.E., Harrison, S. \& Jordan, J.T. 2013. Sea level rise and submarine mass failures on open continental margins. Quaternary Science Reviews, 82, 93-103.

Smith, R.C., Hill, J., Collins, G.S., Piggott, M.D., Kramer, S.C., Parkinson, S.D. \& Wilson, C. 2016. Comparing approaches for numerical modelling of tsunami generation by deformable submarine slides. Ocean Modelling, 100, 125-140.

SPISKE, M., BöröcZ, Z. \& BAHLBURG, H. 2008. The role of porosity in discriminating between tsunami and hurricane emplacement of boulders - a case study from the Lesser Antilles, southern Caribbean. Earth and Planetary Science Letters, 268, 384-396. 


\section{R. TAPPIN}

Spiske, M., Weiss, R., Bahlburg, H., Roskosch, J. \& AmiJaya, H. 2010. The TsuSedMod inversion model applied to the deposits of the 2004 Sumatra and 2006 Java tsunami and implications for estimating flow parameters of palaeo-tsunami. Sedimentary Geology, 224, 29-37.

Spiske, M., Bahlburg, H. \& Weiss, R. 2014. Pliocene mass failure deposits mistaken as submarine tsunami backwash sediments - An example from Hornitos, northern Chile. Sedimentary Geology, 305, 69-82.

Stearns, H.T. 1978. Quaternary shorelines in the Hawaiian Islands. Bernice P. Bishop Museum Bulletin, 237, 57.

Stearns, H.T. \& Macdonald, G.A. 1946. Geology and groundwater resources of the Island of Hawaii. Hawaii Division of Hydrography Bulletin, 9, 393.

Sugawara, D. \& Goto, K. 2012. Numerical modeling of the 2011 Tohoku-oki tsunami in the offshore and onshore of Sendai Plain, Japan. Sedimentary Geology, 282, 110-123.

Sugawara, D., Goto, K., Imamura, F., Matsumoto, H. \& Minoura, K. 2012. Assessing the magnitude of the 869 Jogan tsunami using sedimentary deposits: prediction and consequence of the 2011 Tohoku-oki tsunami. Sedimentary Geology, 282, 14-26.

Sugawara, D., Imamura, F., Goto, K., Matsumoto, H. \& Minoura, K. 2013. The 2011 Tohoku-oki Earthquake Tsunami: similarities and differences to the 869 Jogan Tsunami on the Sendai Plain. Pure and Applied Geophysics, 170: 831, https://doi.org/10. 1007/s00024-012-0460-1

Sugawara, D., Goto, K. \& Jaffe, B.E. 2014. Numerical models of tsunami sediment transport - current understanding and future directions. Marine Geology, 352, 295-320.

SvendSen, J.1. \& Mangerud, J. 1990. Sea-level changes and pollen stratigraphy on the outer coast of Sunnmøre, western Norway. Norsk Geologisk Tidsskrift, 70, $111-134$.

Sweet, S. \& Silver, E.A. 2003. Tectonics and slumping in the source region of the 1998 Papua New Guinea tsunami from seismic reflection images. Pure and Applied Geophysics, 160, 1945-1968.

SwitZer, A.D. \& Burston, J.M. 2010. Competing mechanisms for boulder deposition on the southeast Australian coast. Geomorphology, 114, 42-54.

Switzer, A.D., Pucillo, K., Haredy, R.A., Jones, B.G. \& BRYANT, E.A. 2005. Sea level, storm, or tsunami: enigmatic sand sheet deposits in a sheltered coastal embayment from southeastern New South Wales, Australia. Journal of Coastal Research, 21, 655-663.

SynOlaKIs, C.E. \& Bernard, E.N. 2006. Tsunami science before and beyond Boxing Day 2004. Philosophical Transactions of the Royal Society of London A: Mathematical, Physical and Engineering Sciences, 364, 2231-2265.

SzcZUCIŃsKI, W. 2011. The post-depositional changes of the onshore 2004 tsunami deposits on the Andaman Sea coast of Thailand. Natural Hazards, 60, $115-133$.

SzCZUCIŃSKI, W. 2013. Limitations of tsunami deposits identification - problem of sediment sources, sedimentary environments and processes, and post-depositional changes. 4th International INQUA Meeting on
Paleoseismology, Active Tectonics and Archeoseismology (PATA). INQUA Focus Group on Paleoseismology and Active Tectonics, Aachen, Germany.

Szczuciński, W., KoKociński, M., Rzeszewski, M., Chagué-Goff, C., CaChão, M., Goto, K. \& SugaWARA, D. 2012. Sediment sources and sedimentation processes of 2011 Tohoku-oki tsunami deposits on the Sendai Plain, Japan - insights from diatoms, nannoliths and grain size distribution. Sedimentary Geology, 282, 40-56.

TALLING, P.J. 2014. On the triggers, resulting flow types and frequencies of subaqueous sediment density flows in different settings. Marine Geology, 352, 155-182.

TALling, P.J., WynN, R.B. ET AL. 2007. Onset of submarine debris flow deposition far from original giant landslide. Nature, 450, 541-544.

Talling, P.J., Clare, M., Urlaub, M., Pope, E., Hunt, J.E. \& WATT, S.F.L. 2014. Large submarine landslides on continental slopes: geohazards, methane release, and climate change. Oceanography, 27, 32-45.

TANG, H. \& Weiss, R. 2015. A model for tsunami flow inversion from deposits (TSUFLIND). Marine Geology, 370, 55-62.

TAPPIN, D.R. 2007. Sedimentary features of tsunami deposits - their origin, recognition and discrimination: an introduction. Sedimentary Geology, 200, 151-154.

TAPPIN, D.R. 2009. Mass transport events and their tsunami hazard. In: Mosher, D.C., SHIPP, R.C., Moscardilli, L., Chaytor, J.D., Baxter, C.D.P., Lee, H.J. \& Urgeles, R. (ed.) Submarine Mass Movements and Their Consequences. Springer Science + Business Media, Dordrecht, Heidelberg, London, New York, 667-684.

TAPPIN, D.R. 2010a. Digital elevation models in the marine domain: investigating the offshore tsunami hazard from submarine landslides. In: Fleming, C., Marsh, S.H. \& GiLES, J.R.A. (eds) Elevation Models for Geoscience. Geological Society, London, Special Publications, London, 81-101, https://doi.org/10. 1144/SP345.10

TAPPIN, D.R. 2010b. Submarine mass failures as tsunami sources - their climate control. Philosophical Transactions of the Royal Society A, 368, 2317-2368.

Tappin, D.R., Matsumoto, T. et aL. 1999. Sediment slump likely caused 1998 Papua New Guinea Tsunami. EOS, Transactions of the American Geophysical Union, 80, 329, 334, 340.

TAPPIN, D.R., WatTs, P., McMurtry, G.M., LAFOY, Y. \& Matsumoto, T. 2001. The Sissano Papua New Guinea tsunami of July 1998 - offshore evidence on the source mechanism. Marine Geology, 175, 1-23.

Tappin, D.R., McNeil, L., Henstock, T. \& Mosher, D. 2007. Mass wasting processes - offshore Sumatra. In: Lykousis, V., Sakellarious, D. \& Locat, J. (eds) Submarine Mass Movements and Their Consequences. Springer, Dordrecht, 327-336.

TapPin, D.R., WatTs, P. \& GRILli, S.T. 2008. The Papua New Guinea tsunami of 17 July 1998: anatomy of a catastrophic event. Natural Hazards and Earth System Sciences, 8, 243-266.

Tappin, D.R., Evans, H.M., Richmond, B., Sugawara, D. \& Goto, K. 2012. Coastal changes in the Sendai area from the impact of the 2011 Tōhoku-oki tsunami: interpretations of time series satellite images, 


\section{IMPORTANCE OF GEOLOGY IN TSUMANI SCIENCE}

helicopter-borne video footage and field observations. Sedimentary Geology, 282, 151-174.

TAPPIN, D.R., GRILLI, S.T. ET AL. 2014. Did a submarine landslide contribute to the 2011 Tohoku tsunami? Marine Geology, 357, 344-361.

Tehranirad, B., Harris, J., Grilli, A., Grilli, S., Abadie, S., Kirby, J. \& Shi, F. 2015. Far-field tsunami impact in the North Atlantic Basin from large scale flank collapses of the Cumbre Vieja Volcano, La Palma. Pure and Applied Geophysics, 172, 3589-3616.

TEN BRINK, U. 2009. Tsunami hazard along the U.S. Atlantic coast. Marine Geology, 264, 1-3.

ten Brink, U.S., Lee, H.J., Geist, E.L. \& Twichell, D. 2009. Assessment of tsunami hazard to the U.S. East Coast using relationships between submarine landslides and earthquakes. Marine Geology, 264, 65-73.

ten Brink, U.S., Chaytor, J.D., Geist, E.L., Brothers, D.S. \& ANDREws, B.D. 2014. Assessment of tsunami hazard to the U.S. Atlantic margin. Marine Geology, 353, 31-54.

Ten Brink, U.S., Andrews, B.D. \& Miller, N.C. 2016. Seismicity and sedimentation rate effects on submarine slope stability. Geology, 44, 563-566.

Tinti, S., Bortolucci, E. \& Chiavettieri, C. 2001. Tsunami excitation by submarine slides in shallowwater approximation. Pure and Applied Geophysics, 158, 759-797.

Tsuru, T., Park, J.-O., Miura, S., Kodaira, S., Kido, Y. \& HAYASHI, T. 2002. Along-arc structural variation of the plate boundary at the Japan Trench margin: implication of interplate coupling. Journal of Geophysical Research, 107, 2357.

TURNER, A.K. \& SCHUSTER, R.L. 1996. Landslides: Investigation and Mitigation. Special Report 247, Transportation Research Board, National Academy Press, Washington, DC.

Tuttle, M.P., Ruffman, A., Anderson, T. \& Jeter, H. 2004. Distinguishing tsunami from storm deposits in eastern North America: the 1929 Grand Banks tsunami v. the 1991 Halloween storm. Seismological Research Letters, 75, 117-131.

Twichell, D.C., Chaytor, J.D., ten Brink, U.S. \& BUCZKOWSKI, B. 2009. Morphology of late Quaternary submarine landslides along the U.S. Atlantic continental margin. Marine Geology, 264, 4-15.

Ulvrova, M., Paris, R., Nomikou, P., Kelfoun, K., LeibrandT, S., Tappin, D.R. \& McCoy, F.W. 2016. Source of the tsunami generated by the 1650 AD eruption of Kolumbo submarine volcano (Aegean Sea, Greece). Journal of Volcanology and Geothermal Research, 321, 125-139.

Urlaub, M., Talling, P.J. \& Masson, D.G. 2013. Timing and frequency of large submarine landslides: implications for understanding triggers and future geohazard. Quaternary Science Reviews, 72, 63-82.

VerbeeK, R.D.M. 1885. Krakatau. Government Press, Batavia.

von Huene, R., Klaeschen, D., Cropp, B. \& Miller, J. 1994. Tectonic structure across the accretionary and erosional parts of the Japan Trench margin. Journal of Geophysical Research, 99, 22349-22361.

von Huene, R., Kirby, S., Miller, J. \& Dartnell, P. 2014. The destructive 1946 Unimak near-field tsunami: new evidence for a submarine slide source from reprocessed marine geophysical data. Geophysical Research Letters, 41, 6811-6818.

WARD, S.N. 2001. Landslide tsunami. Journal of Geophysical Research, 106, 11201-11215.

WARD, S.N. \& DAY, S. 2001. Cumbre Vieja volcano - potential collapse and tsunami at La Palma, Canary Islands. Geophysical Research Letters, 28, 3397-3400.

Wassmer, P., Schneider, J.-L., Fonfrège, A.-V., LaVIGNe, F., PARIS, R. \& Gomez, C. 2010. Use of anisotropy of magnetic susceptibility (AMS) in the study of tsunami deposits: application to the 2004 deposits on the eastern coast of Banda Aceh, North Sumatra, Indonesia. Marine Geology, 275, 255-272.

WatTs, P. 1997. Water waves generated by underwater landslides. Unpublished $\mathrm{PhD}$ thesis. California Institute of Technology, Pasadena, CA.

WATTS, P. 1998. Wavemaker curves for tsunamis generated by underwater landslides. Journal of Waterway, Port, Coastal, and Ocean Engineering, 124, 127-137.

WATTS, P. 2000. Tsunami features of solid block underwater landslides. Journal of Waterway, Port, Coastal, and Ocean Engineering, 126, https://doi.org/10.1061/ (ASCE)0733-950X(2000)126:3(144)

WatTs, P. 2004. Probabilistic predictions of landslide tsunamis off Southern California. Marine Geology, 203, 281-301.

Watts, P., Borrero, J.C., Tappin, D.R., Bardet, J.-P., GrILli, S.T. \& Synolakis, C.E. 1999. Novel simulation technique employed on the 1998 Papua New Guinea tsunami (abs). Proceedings of 22nd General Assembly IUGG, Birmingham, UK, JSS42.

Watts, P., Grilli, S.T., Kirby, J.T., Fryer, G.J. \& TapPIN, D.R. 2003. Landslide tsunami case studies using a Boussinesq model and a fully nonlinear tsunami generation model. Natural Hazards and Earth System Science, 3, 391-402.

Watts, P., Grilli, S.T., Tappin, D.R. \& Fryer, G.J. 2005. Tsunami generation by submarine mass failure part II: predictive equations and case studies. Journal of Waterway, Port, Coastal, and Ocean Engineering, 131, 298-310.

Webster, J.M., George, N.P.J. ET AL. 2016. Submarine landslides on the Great Barrier Reef shelf edge and upper slope: a mechanism for generating tsunamis on the north-east Australian coast? Marine Geology, 371, 120-129.

WeIss, R. 2008. Sediment grains moved by passing tsunami waves: tsunami deposits in deep water. Marine Geology, 250, 251-257.

WeIss, R. 2012. The mystery of boulders moved by tsunamis and storms. Marine Geology, 295-298, 28-33.

WeIss, R. \& DiPLAS, P. 2015. Untangling boulder dislodgement in storms and tsunamis: is it possible with simple theories? Geochemistry, Geophysics, Geosystems, 16, 890-898.

Witter, R., Jaffe, B., Zhang, Y. \& Priest, G. 2012. Reconstructing hydrodynamic flow parameters of the 1700 tsunami at Cannon Beach, Oregon, USA. Natural Hazards, 63, 223-240.

Wright, C. \& Mella, A. 1963. Modifications to the soil pattern of South-Central Chile resulting from seismic and associated phenomenona during the period May to August 1960. Bulletin of the Seismological Society of America, 53, 1367-1402. 


\section{R. TAPPIN}

1915

1916

1917

1918

1919

1920

1921

1922

1923

1924

1925

1926

1927

1928

1929

1930

1931

1932

1933

1934

1935

1936

1937

1938

1939

1940

1941

1942

1943

1944

1945

1946

1947

1948

1949

1950

1951

1952

1953

1954

1955

1956

1957

1958

1959

1960

1961

1962

1963

1964

1965

1966

1967

1968

1969

1970

1971

1972
Yamada, M., Fujino, S. \& Goto, K. 2014. Deposition of sediments of diverse sizes by the 2011 Tohoku-oki tsunami at Miyako City, Japan. Marine Geology, 358, 67-78.

YAMAZAKI, Y., Cheung, K.F. \& LaY, T. 2013. Modeling of the 2011 Tohoku Near-Field Tsunami from
Finite-Fault Inversion of Seismic Waves. Bulletin of the Seismological Society of America, 103, 1444-1455. Yeh, H., Imamura, F., Synolakis, C., Tsuji, Y., Liu, P. \& SHI, S.Z. 1993. The Flores Island Tsunamis. EOS, Transactions of the American Geophysical Union, 74, 369, 371-373. 